\title{
Asymmetric Organocatalysis Revisited: Taming Hydrindanes with Jørgensen-Hayashi Catalyst
}

\author{
Yannick Stöckl \\ Wolfgang Frey \\ Johannes Lang \\ Birgit Claasen \\ Angelika Baro \\ Sabine Laschat* (D)
}

Institut für Organische Chemie, Universität Stuttgart, Pfaffenwaldring 55 ,

70569 Stuttgart, Germany

sabine.laschat@oc.uni-stuttgart.de

Published as part of the 50 Years SYNTHESIS - Golden Anniversary Issue
Received: 12.11.2018

Accepted: 15.11 .2018

Published online: 14.12 .2018

DOI: 10.1055/s-0037-1610409; Art ID: ss-2018-z0760-fa

License terms: cc)

Abstract The organocatalytic Michael reaction of easily available 1-cyclopentene-1-carbaldehyde and 1,3-dicarbonyl compounds led to cyclopentanecarbaldehydes on a gram scale with low catalyst loading (2 mol\%) and high enantioselectivity. The synthetic potential of 4-acylhexahydroindenones from intramolecular aldol condensation was demonstrated by Diels-Alder reaction to a tetracyclic derivative with seven stereogenic centers. The diastereofacial preference of the tetracyclic product was confirmed by DFT calculations. The described reaction sequence is characterized by few redox-economic steps and high degree of molecular complexity.

Key words organocatalysis, hydrindane, Jørgensen-Hayashi catalyst, Michael addition, aldol condensation, Diels-Alder reaction

Since the pioneering work by Wiechert ${ }^{1}$ and Parrish ${ }^{2}$ in the early seventies on proline-catalyzed aldol reactions, ${ }^{3}$ the field of asymmetric organocatalysis has made tremendous progress. ${ }^{4}$ Among the numerous organocatalysts developed so far, the Jørgensen-Hayashi catalyst and structurally related diarylprolinol silyl ethers have turned out very successful and reliable in a huge variety of different reactions. ${ }^{5}$ Depending on the substrates, Jørgensen-Hayashi catalyst operates either through HOMO activation of aldehydes via enamine intermediates or LUMO activation of enals via iminium ion intermediates. Detailed mechanistic insight was gained by NMR spectroscopy, kinetic experiments, reaction calorimetry, and computational studies. 6,7 In addition, several strategies for immobilization have been successfully developed. ${ }^{8}$ Interesting targets for organocatalysis are substituted hydrindanes $\mathbf{1}$, that is, bicyclo[4.3.0]nonanes, which are important scaffolds of natural products and synthetic bioactive compounds. Selected ex-

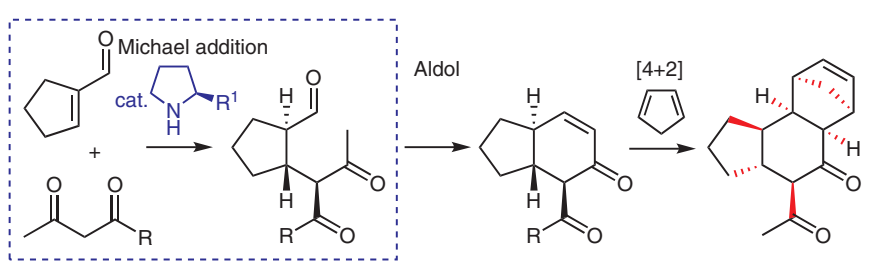

amples are amaminol A (2), ${ }^{9}$ the tricyclic unit of ikarugamycin (3), ${ }^{10}$ or the $\mathrm{CD}$ ring unit of deoxycholic acid $(4)^{11}$ (Figure 1).

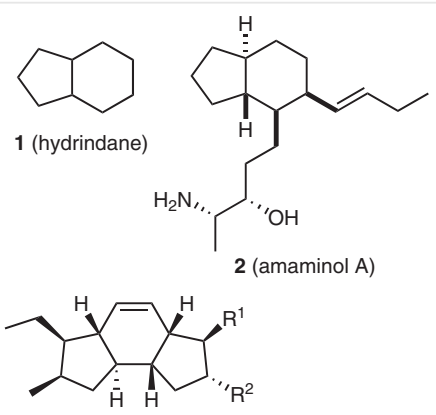

3 (tricyclic unit of ikarugamycin)

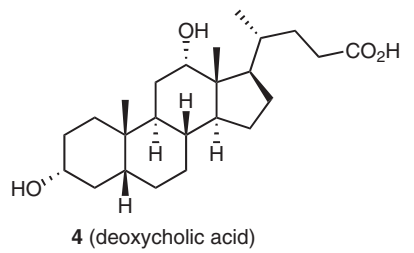

Figure 1 Bicyclo[4.3.0]nonane (hydrindane, 1) and some selected examples of compounds $\mathbf{2 - 4}$ containing this structural motif

Various synthetic methods have been developed to access the bicyclo[4.3.0]nonane core, ${ }^{12}$ most notably Diels-Alder reactions, ${ }^{13-17}$ Pauson-Khand reactions of alkenes and alkynes or enynes with carbon monoxide, ${ }^{18}$ radical cyclizations, ${ }^{19}$ titanacycle-mediated annulations, ${ }^{20}$ intramolecular aldol and Michael reactions, ${ }^{21}$ Morita-Baylis-Hillman reactions, $22-24$ sequential ring-opening/ring-closing metathesis, ${ }^{25-27}$ and enyne metathesis, ${ }^{28}$ or one-pot consecutive Pdcatalyzed Overman rearrangement, Ru-catalyzed ring closing enyne metathesis, and hydrogen bond-directed DielsAlder reaction..$^{29}$ Particular valuable hydrindanes are hexa- 


\section{Biographical Sketches}
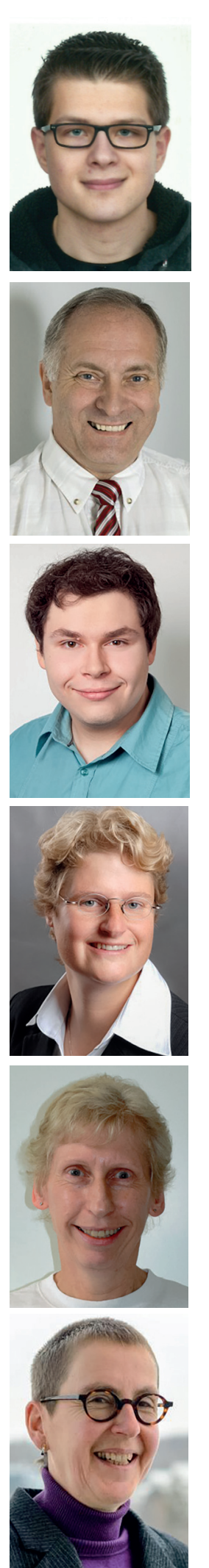

Yannick Stöckl studied chemistry at the University of Stuttgart (20132016). In his B.Sc. thesis in the Laschat research group, he focused on the synthesis and characteriza-

Wolfgang Frey received his Ph.D. in 1991 in Organic Structure Chemistry at the University of Stuttgart,

Johannes Lang is an independent researcher within the Institute of Organic Chemistry at the University of Stuttgart, Germany. He obtained his

Birgit Claasen studied chemistry in Hamburg and obtained her Ph.D. in the research group of Prof. Meyer, where she studied biomolecular interactions by NMR spectroscopy. In

Angelika Baro studied chemistry at the Georg-August-Universität Göttingen (Germany), where she re-

Sabine Laschat studied chemistry at the University of Würzburg (1982-1987) and did her Ph.D. at the University of Mainz under the supervision of Horst Kunz (19881990). After postdoctoral studies with Larry E. Overman at the University of California, Irvine (19901991), followed by her habilitation tion of liquid crystalline merocyanines (2016) and in his M.Sc. thesis, he worked on the formation of bi- and polycyclic natural product scaffolds (2018). In 2016, he joined

Germany. Since 1996 he is responsible for the structure determination of single crystal X-ray diffraction

Ph.D. at the University of Kaiserslautern elucidating geometrical and electronic structures of gaseous ions. His current research interests

her post-doctoral fellowship in the group of Prof. Giralt at the Barcelona Science Park, Spain, she applied NMR spectroscopy to large proteins to study protein dynamics. In 2009 ,

ceived her Ph.D. in Clinical Biochemistry (1987). Since 1991 at the Institute of Organic Chemistry, Uni-

at the University of Münster, she was appointed as Associate Professor at the TU Braunschweig (19972002). Since 2002 she is Full Professor of Organic Chemistry at the University of Stuttgart. She was speaker of the Cooporative Research Centre SFB 706 'Selective catalytic oxidations with $\mathrm{C}-\mathrm{H}$ bonds with molecu- the research group of Louis C. Morrill, Cardiff University, for 3 months (DAAD-RISE fellowship). The aim of his Ph.D. project is the synthesis of polycyclic natural products.

data at the Institute of Organic Chemistry.

include spectroscopic and theoretical studies of organic molecules and coordination compounds.

she joined the analytical department of organic chemistry in Stuttgart, where she is focused on structure elucidation by spectroscopic techniques.

versity of Stuttgart, she is responsible for scientific documentation and publication.

lar oxygen' (2005-2010), served as Vice Rector for Research and Technology of the University of Stuttgart (2010-2012), and is currently speaker of the project house 'NanoBioMater'. Her research interests include liquid crystals, natural product synthesis, and chemoenzymatic syntheses. 
hydroindenones whose enone moiety allows further functionalization. ${ }^{12}$ Their archetypal organocatalytic synthesis relies on the proline-catalyzed aldol condensation towards Hajos-Parrish diketone 5 (Scheme 1), 2,30 which was further functionalized in multiple ways to the desired hydrindane target compounds. The unsubstituted member 7 of the hexahydroindenone family was obtained via sequential intramolecular Michael addition/aldol condensation of enone $\mathbf{8}$ in the presence of MacMillan imidazolidine catalyst (Scheme 1). ${ }^{31}$

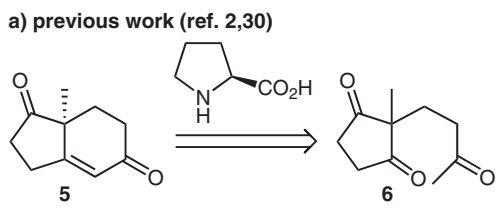

b) previous work (ref. 31)

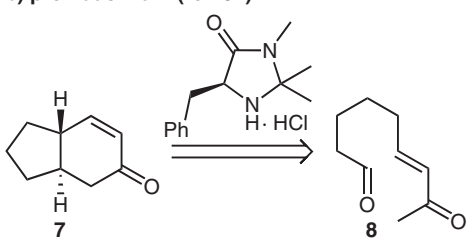

c) this work<smiles>[R]C(=O)CC([R])=O</smiles>

Scheme 1 Previous retrosynthetic steps to hexahydroindenones and the herein envisioned pathway to oxo-functionalized hexahydroinden5-ones 9

When considering potential organocatalytic routes to hexahydroindenones we identified the 4-substituted derivative $\mathbf{9}$ as a promising target for further manipulation. To access compound $\mathbf{9}$ from easily available starting materials, we envisaged an intermolecular Michael addition of 1,3-dicarbonyl compounds 12 to 1-cyclopentene-1-carbaldehyde (11) followed by aldol condensation of the resulting intermediate $\mathbf{1 0}$ (Scheme 1). Surprisingly, little is known about the use of 1-cyclopentene-1-carbaldehyde (11) in organocatalytic Michael additions. ${ }^{32-36}$ On the other hand, simple 1,3-carbonyl compounds such as acetylacetone and ethyl acetoacetate were only rarely employed in organocatalytic Michael additions. ${ }^{37,38}$ Thus, we aimed at a robust and reliable route towards hydrindanes $\mathbf{9}$, which should be amenable to preparative scale while requiring a minimum catalyst loading. Furthermore, we wanted to probe functionalizations of compound $\mathbf{9}$ towards tri- or polycyclic scaffolds.

In preliminary experiments, the influence of different catalysts on the Michael addition of acetylacetone (12a) to 1-cyclopentene-1-carbaldehyde $(\mathbf{1 1})^{39}$ was studied
(Table 1). When 11 and 12a were reacted in EtOH for 24 hours without catalyst, no conversion of the starting material 11 was observed by ${ }^{1} \mathrm{H}$ NMR analysis (Table 1, entry 1 ). In the presence of catalysts pyrrolidine (13a; $50 \mathrm{~mol} \%$ ) and L-proline (13b; 30 mol\%), respectively, addition product 10a was isolated in only $3 \%$ and $4 \%$ yield due to decomposition of 10a upon chromatographic purification (entries 2 and 3). The use of Jørgensen-Hayashi catalyst 13c (20 mol\%), however, provided 10a in 58\% NMR yield with 94\% ee (entry 4). A solvent screening for the Michael reaction (Table 1) resulted in toluene as optimal solvent giving 10a in 70\% yield and $97 \%$ ee (entry 11), while additives such as AcOH deteriorated yield and selectivity (entry 12 ).

Table 1 Optimization of Conditions for the Organocatalytic 1,4-Addition of Acetylacetone (12a) to 1-Cyclopentene-1-carbaldehyde (11)

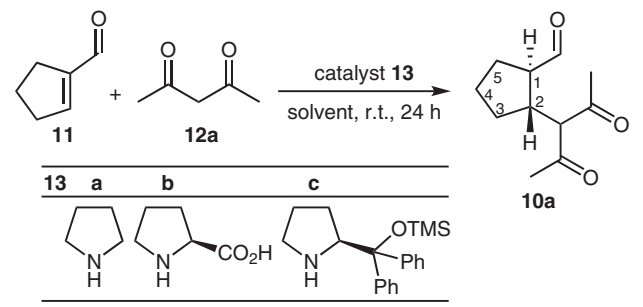

\begin{tabular}{|c|c|c|c|c|}
\hline Entry & Catalyst (mol\%) & Solvent & Yield (\%) & $e e(\%)^{a}$ \\
\hline 1 & - & $\mathrm{EtOH}$ & - & - \\
\hline 2 & $13 a(50)$ & $\mathrm{EtOH}$ & 3 & - \\
\hline 3 & 13b (30) & $\mathrm{EtOH}$ & 4 & 5 \\
\hline 4 & $13 c(20)$ & $\mathrm{EtOH}$ & $58^{b}$ & 94 \\
\hline 5 & $13 c(20)$ & $\mathrm{MeOH}$ & 43 & 89 \\
\hline 6 & $13 c(20)$ & $\mathrm{H}_{2} \mathrm{O}$ & 45 & 89 \\
\hline 7 & $13 c(20)$ & THF & 55 & 89 \\
\hline 8 & $13 c(20)$ & $\mathrm{MeCN}$ & 60 & 90 \\
\hline 9 & $13 c(20)$ & $\mathrm{CHCl}_{3}$ & 60 & 90 \\
\hline 10 & $13 c(20)$ & hexane & 39 & 94 \\
\hline 11 & $13 c(20)$ & toluene & 70 & 97 \\
\hline 12 & $13 c(20)$ & toluene ${ }^{c}$ & 52 & 92 \\
\hline
\end{tabular}

a Determined by GC on a chiral stationary phase.

${ }^{b}$ Determined by ${ }^{1} \mathrm{H}$ NMR spectroscopy with $1,3,5$-trimethylbenzene $(0.53$ equiv) as an internal standard.

c AcOH as additive.

Next, the robustness of the Michael addition with respect to catalyst loading and scale was studied (Table 2 ). Reducing the amount of organocatalyst 13c from $5 \mathrm{~mol} \%$ to $2.5 \mathrm{~mol} \%$ required longer reaction times but both yield and ee values remained constant (Table 2, entries 1 and 2 ). The best result was realized with $2 \mathrm{~mol} \%$ of $13 \mathrm{c}$ and convenient purification by simple filtration over a silica pad yielding 10a in $72 \%$ with $98 \%$ ee even on a $10 \mathrm{mmol}$ scale (entry 4 ). It should be emphasized that the catalyst loading under these 
Table 2 Optimization of Catalyst Loading and Scale

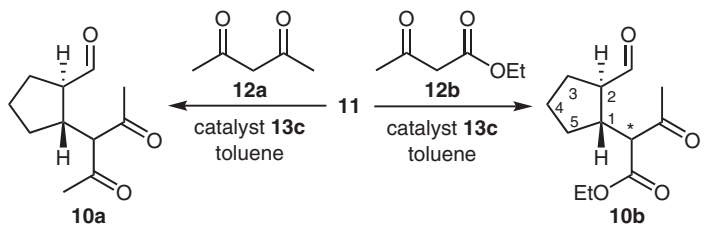

\begin{tabular}{|c|c|c|c|c|c|c|c|c|c|}
\hline Entry & 11 (mmol) & $13 \mathrm{c}(\mathrm{mol} \%)$ & 12 (equiv) & Temp & Time (h) & 10 & Yield (\%) & $e e(\%)^{b}$ & d.r. \\
\hline $1^{c}$ & 10 & 5 & 1.0 & r.t. & 26 & a & 52 & 97 & - \\
\hline $2^{c}$ & 3 & 2.5 & 1.0 & r.t. & 38 & a & 52 & 97 & - \\
\hline $3^{c}$ & 3 & 0.5 & 1.0 & r.t. & 48 & a & 40 & n.d. & - \\
\hline $4^{\mathrm{d}}$ & 10 & 2 & 1.0 & $0{ }^{\circ} \mathrm{C} \rightarrow$ r.t. & 60 & a & 72 & 98 & - \\
\hline $5^{d}$ & 1 & 2 & 1.5 & $0{ }^{\circ} \mathrm{C} \rightarrow$ r.t. & 18 & a & 61 & n.d. & - \\
\hline $6^{c}$ & 2 & 2 & 1.0 & r.t. & 24 & b & 91 & - & $50: 50$ \\
\hline $7^{d}$ & 4 & 2 & 1.0 & r.t. & 60 & b & 82 & - & $50: 50$ \\
\hline $8^{c}$ & 1 & 2 & neat & $0{ }^{\circ} \mathrm{C} \rightarrow$ r.t. & 24 & b & 30 & - & $50: 50$ \\
\hline
\end{tabular}

a Isolated yields.

b Determined by GC on a chiral stationary phase. n.d.: Not determined.

'Flash chromatography.

${ }^{\mathrm{d}}$ Filtration over a silica pad.

optimized conditions is ten times lower than that of the initial experiments in Table 1. Further decrease of the catalyst loading was accompanied by reduced yield (entry 3 ).

When ethyl acetoacetate (12b) was employed as nucleophile under the optimized conditions, addition product 10b was isolated in $91 \%$ as a (50:50) diastereomeric mixture after flash chromatography (Table 2, entry 6). Unfortunately, the enantioselectivity could not be determined by GC or HPLC on chiral stationary phases. Longer reaction time or the use of neat 12b without any solvent reduced the yield (entries 7 and 8 ).

In order to determine the enantioselectivity of the Michael addition with acetoacetate $\mathbf{1 2 b}$ by an indirect method, a sequential Michael addition/Wittig olefination was performed (Scheme 2). Following Method A, cyclopentene-

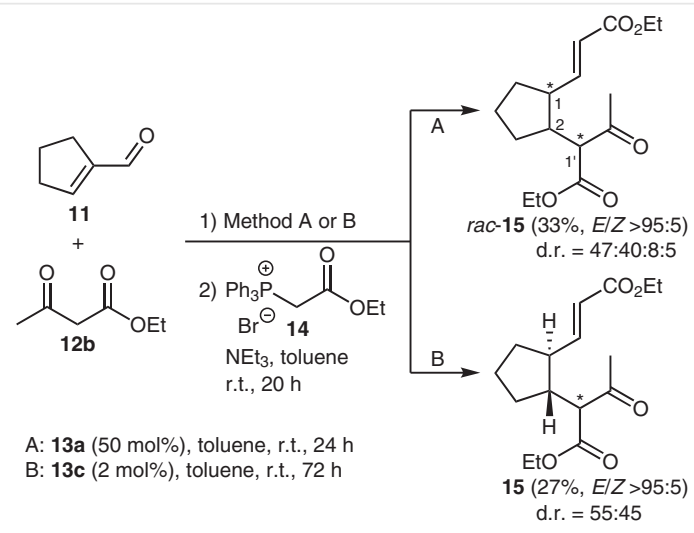

Scheme 2 Sequential Michael addition/Wittig olefination carbaldehyde $\mathbf{1 1}$ and acetoacetate $\mathbf{1 2 b}$ were reacted in the presence of catalyst 13a (50 mol\%) in toluene for 24 hours at room temperature and subsequently treated with phosphonium salt 14 in toluene in the presence of $\mathrm{NEt}_{3}$. After workup, racemic cyclopentane enoate rac-15 was isolated with an $E / Z$ ratio of $>95: 5$ and a diastereomeric ratio of 47:40:8:5. In a parallel experiment Jørgensen-Hayashi catalyst $13 \mathrm{c}$ ( $2 \mathrm{~mol} \%$ ) was used (Method B) resulting in the trans-disubstituted cyclopentane enoate $\mathbf{1 5}$ in $27 \%$ yield $(E / Z>95: 5$, d.r. $55: 45)$.

Taking the preferred formation of the trans-disubstituted cyclopentanecarbaldehyde $(1 R, 2 R)-10 a$ with excellent enantioselectivity (e.r. 99:1) into account, we surmised that a similar enantiofacial discrimination was obtained in the Michael addition of acetoacetate $\mathbf{1 2 b}$, resulting in the two diastereomeric products $\left(1 R, 2 R, 1^{\prime} S\right)-\mathbf{1 0 b}$ and $\left(1 R, 2 R, 1^{\prime} R\right)$ $\mathbf{1 0 b}$ in a diastereomeric ratio of $(55: 45)$ due to the lack of stereochemical control at the $\alpha$-carbon of the 1,3-dicarbon$\mathrm{yl}$ unit. Moreover, the formation of four diastereomeric cyclopentane enoates 15 (d.r. 47:40:8:5) under racemic conditions presumably coming from four diastereomeric cyclopentane carbaldehydes $\mathbf{1 0 b}$ with a similar ratio suggested that besides the two trans-disubstituted diastereomers $\left(1 R, 2 R, 1^{\prime} S\right)-\mathbf{1 0 b}$ and $\left(1 R, 2 R, 1^{\prime} R\right)-\mathbf{1 0 b}$ also the corresponding cis-diastereomers $\left(1 R, 2 S, 1^{\prime} S\right)$-10b and $\left(1 R, 2 S, 1^{\prime} R\right)$-10b were formed. Hence the Jørgensen-Hayashi catalyst 13c not only exerts a stereochemical control on the enantiofacial differentiation but also on the diastereofacial differentiation of the $\mathrm{C}=\mathrm{C}$ double bond of the Michael acceptor in agreement with previous work by Bernardi. ${ }^{34}$ 
Table 3 Optimization of Intramolecular Aldol Condensation of $\mathbf{1 0}$

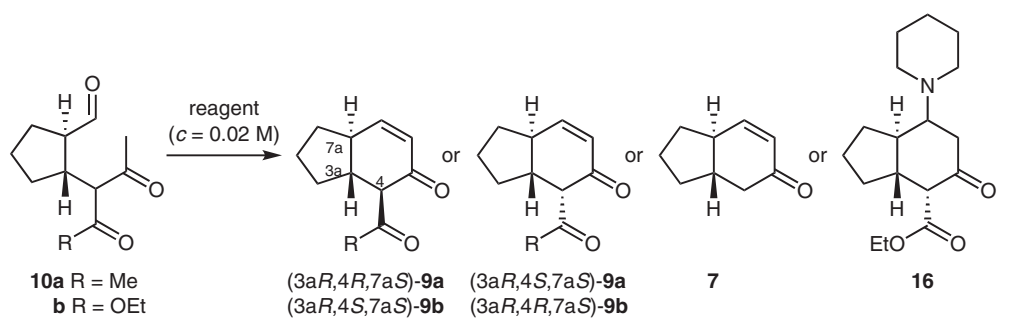

\begin{tabular}{|c|c|c|c|c|c|c|}
\hline Entry & Reagent (equiv) & Solvent & $\operatorname{Temp}\left({ }^{\circ} \mathrm{C}\right)$ & Time (h) & Product & Yield (\%) \\
\hline 1 & $\mathrm{KOH}$ & $\mathrm{MeOH}$ & $0 \rightarrow$ r.t. & 2 & $9 a$ & - \\
\hline 2 & $\begin{array}{l}\text { 1) } \mathrm{KOH} \\
\text { 2) } \mathrm{MsCl}^{\mathrm{a}}\end{array}$ & $\begin{array}{l}\mathrm{MeOH} \\
\mathrm{CH}_{2} \mathrm{Cl}_{2}\end{array}$ & $\begin{array}{l}0 \rightarrow \text { r.t. } \\
\text { r.t. }\end{array}$ & $\begin{array}{r}2 \\
17\end{array}$ & 7 & 50 \\
\hline 3 & $\mathrm{TsOH}(0.1)$ & toluene & reflux & 3 & $9 a$ & 5 \\
\hline 4 & $\mathrm{TsOH}(0.05)$ & toluene & r.t. & 24 & $9 a$ & - \\
\hline 5 & $\mathrm{TsOH}(0.05)$ & toluene & 50 & 36 & $9 a$ & 23 \\
\hline 6 & $\mathrm{TsOH}(0.05)$ & THF & 50 & 24 & $9 a$ & - \\
\hline 7 & $\mathrm{TsOH}(0.05)$ & $\mathrm{MeOH}$ & 50 & 16 & $9 a$ & - \\
\hline 8 & PPTS (0.05) & toluene & reflux ${ }^{b}$ & 7 & $9 a$ & 50 \\
\hline 9 & PPTS (1.0) & toluene & reflux ${ }^{b}$ & 3 & $9 a$ & 55 \\
\hline 10 & $(-)-\operatorname{CSA}(1.0)$ & toluene & reflux ${ }^{b}$ & 1 & $9 a$ & 55 \\
\hline 11 & $(-)-\operatorname{CSA}(1.0)$ & toluene & 50 & 72 & $9 a$ & 73, d.r. $94: 6$ \\
\hline 12 & $(+)-\operatorname{CSA}(1.0)$ & toluene & 50 & 65 & $9 a$ & 71, d.r. 93:7 \\
\hline 13 & $(-)-\operatorname{CSA}(1.0)$ & toluenec & 50 & 96 & $9 b$ & 19 \\
\hline 14 & piperidine/CSA & toluene $^{c}$ & 50/reflux & $\begin{array}{c}24 \\
1.5\end{array}$ & $\begin{array}{l}16 \\
9 b\end{array}$ & 12 \\
\hline 15 & $\begin{array}{l}\text { 1) } \mathrm{DBU} \\
\text { 2) } \mathrm{MsCl}^{\mathrm{a}}\end{array}$ & $\begin{array}{l}\mathrm{MeOH} \\
\mathrm{CH}_{2} \mathrm{Cl}_{2}\end{array}$ & $\begin{array}{l}0 \\
0 \rightarrow \text { r.t. }\end{array}$ & $\begin{array}{l}2 \\
4\end{array}$ & $9 b$ & 44 , d.r. $91: 9$ \\
\hline
\end{tabular}

a In the presence of $\mathrm{NEt}_{3}$, DMAP.

b Dean-Stark conditions.

${ }^{c} \mathrm{C}=0.03 \mathrm{M}$.

With cyclopentanecarbaldehydes $\mathbf{1 0 a , b}$ in hand, we examined the intramolecular aldol condensation to the hexahydroindenones 9 under various conditions (Table 3 ).

First we used bases as mediator. Treatment of 10a with stoichiometric amounts of $\mathrm{KOH}$ in $\mathrm{MeOH}$ at $0{ }^{\circ} \mathrm{C}$ and warming to room temperature for 2 hours resulted in a complex mixture without any trace of the desired 4-acetylhexahydro-5H-inden-5-one (9a) (Table 3, entry 1 ). As other bases also failed [for details, see Table 51 in Supporting Information (SI)], we followed the method of List, ${ }^{31}$ in which 10a was first deprotonated with $\mathrm{KOH}$ in $\mathrm{MeOH}$ at $0{ }^{\circ} \mathrm{C}$ and subsequently reacted with mesyl chloride in the presence of $\mathrm{NEt}_{3}$ and DMAP in $\mathrm{CH}_{2} \mathrm{Cl}_{2}$. After workup, a single product was isolated in $50 \%$, that, however, was identified as the deacetylated enone 7 (entry 2). Such deacetylation under basic conditions has been reported for several acetylacetone derivatives. ${ }^{40-43}$

Due to the failure of the base-mediated cyclizations, we focused on the corresponding acid-catalyzed aldol condensation. Indeed, treatment of aldehyde 10a with
0.1 equivalent of $\mathrm{TsOH}$ in toluene under reflux for 3 hours gave 9a in 5\% yield (Table 3, entry 3 ). Decrease of TsOH to 0.05 equivalent and the temperature to $50{ }^{\circ} \mathrm{C}$ with extended reaction time ( $36 \mathrm{~h}$ ) improved the yield to $23 \%$ (entry 5 ). In contrast, neither further temperature decrease nor changing the solvent (THF or $\mathrm{MeOH}$ ) gave any of the product 9a (entries 4, 6, and 7). However, PPTS as acid catalyst ( 0.05 equiv) in toluene under Dean-Stark conditions provided $\mathbf{9 a}$ in $50 \%$ yield (entry 8 ). Similar yields were obtained with 1 equivalent of PPTS or (-)-CSA (entries 9 and 10). With 1 equivalent of $(-)$-CSA in toluene at $50{ }^{\circ} \mathrm{C}$ the yield increased to $73 \%$ (d.r. 94:6), (entry 11). The sense of chirality of the Brønsted acid had no impact on yield and diastereoselectivity, that is, (+)-CSA gave 9a in 71\% yield (d.r. 93:7) (entry 12). Under these optimized conditions, however, acetoacetate-derived aldehyde $\mathbf{1 0 b}$ cyclized to $\mathbf{9 b}$ in a disappointingly low yield of $19 \%$ (entry 13). Other Brønsted acids failed completely (Table S2, SI). As piperidine has been reported to promote aldol condensations, ${ }^{44-46}$ aldehyde 10b was submitted to condensation in the presence of piperi- 
dine ( 1 equiv) in toluene at $50{ }^{\circ} \mathrm{C}$ for 24 hours. Monitoring the reaction by ${ }^{1} \mathrm{H}$ NMR spectroscopy and ESI-MS revealed formation of the aldol adduct 16. Upon subsequent addition of 1 equivalent of (-)-CSA to the reaction mixture and stirring for 1.5 hours, only $12 \%$ of $\mathbf{9 b}$ could be isolated (entry 14). Finally, a base-induced aldol addition was tested in which 10b was reacted with 1 equivalent of $\mathrm{DBU}$ in $\mathrm{MeOH}$ at $0{ }^{\circ} \mathrm{C}$ for 2 hours. After acidic workup and addition of $\mathrm{CH}_{2}$ $\mathrm{Cl}_{2}$, the crude product was treated with mesyl chloride, DMAP, and $\mathrm{NEt}_{3}$ for 4 hours to afford indenone $\mathbf{9 b}$ in $44 \%$ yield with a high diastereoselectivity (d.r. 91:9) (entry 15).

A single crystal of $\mathbf{9 a}$ was obtained by crystallization from a diluted solution, which was suitable for X-ray crystal structure analysis (Figure 2). Derivative 9a crystallized with one molecule in the asymmetric unit of the acentric space group P2(1)2(1)2(1). The absolute configuration could be determined from $\mathrm{X}$-ray data by anomalous dispersion characterized by the Flack parameter of $\mathrm{x}=0.08$ (17) revealing the $(3 \mathrm{a} R, 4 R, 7 \mathrm{a} S)$-configuration for the major product of $\mathbf{9 a}$. The five-membered ring system shows an envelope conformation, where C4 is $0.65 \AA$ out of plane. The six-membered ring is characterized by a half-chair conformation with $\mathrm{C} 3$ out of plane $(0.67 \AA) .{ }^{47}$

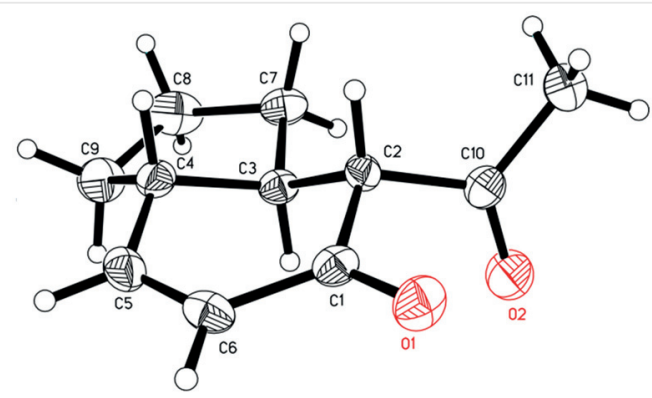

Figure $2 X$-ray crystal structure of enone 9 a. The configuration is $\mathrm{C} 2(R), C 3(R)$, and $C 4(S)$ (X-ray label notation)

As the determination of the enantioselectivity of the Michael addition product 10b had not yet been solved, a sequence of Michael addition/aldol condensation was studied (Scheme 3). For this purpose, $\mathbf{1 1}$ and acetoacetate $\mathbf{1 2 b}$ were treated either with pyrrolidine 13a (50 mol\%, Method A) or Jørgensen-Hayashi catalyst 13c (2 mol\%, Method B) under the usual conditions to yield racemic addition product rac10b in $35 \%$ and enantioenriched $\mathbf{1 0 b}$ in $58 \%$, respectively. Subsequent (-)-CSA-mediated aldol condensation gave $30 \%$ of rac-9b (d.r. 83:17) and 35\% of enantioenriched $\mathbf{9 b}$ (d.r. 86:14). Unfortunately, separation of enantiomers was neither possible via GC nor HPLC on chiral stationary phases.

The relative configuration of racemic enones rac-9b was assigned by 1D and 2D NMR experiments (Figures S1 and $\mathrm{S} 2$ in SI) as trans,trans for the major and trans,cis for the minor diastereomer, respectively. Due to the similarities of the

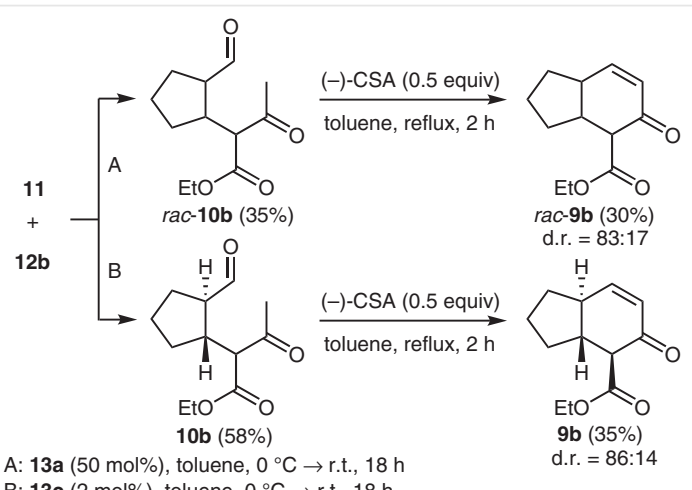

$\mathrm{B}: 13 \mathrm{c}(2 \mathrm{~mol} \%)$, toluene, $0^{\circ} \mathrm{C} \rightarrow$ r.t., $18 \mathrm{~h}$

Scheme 3 Synthesis of racemic and enantioenriched hexahydro- $5 \mathrm{H}$-inden-5-ones $\mathbf{9 b}$

NMR spectra of acetylacetone-derived enones 9a combined with the crystal structure of $(3 \mathrm{a} R, 4 R, 7 \mathrm{a} S)-\mathbf{9 a}$, we assigned the major and the minor diastereomer of the non-racemic acetoacetate-derived enone as $(3 \mathrm{a} R, 4 R, 7 \mathrm{a} S)-\mathbf{9 b}$ and $(3 \mathrm{a} R, 4 S, 7 \mathrm{a} S)-\mathbf{9 b}$.

As mentioned above, hexahydroindenone 9a was assumed as a potential scaffold for convenient functionalization to polycyclic compounds without the necessity to use protecting groups. To realize this goal, we studied the Diels-Alder reaction between 9a and cyclopentadiene (17) (Scheme 4).

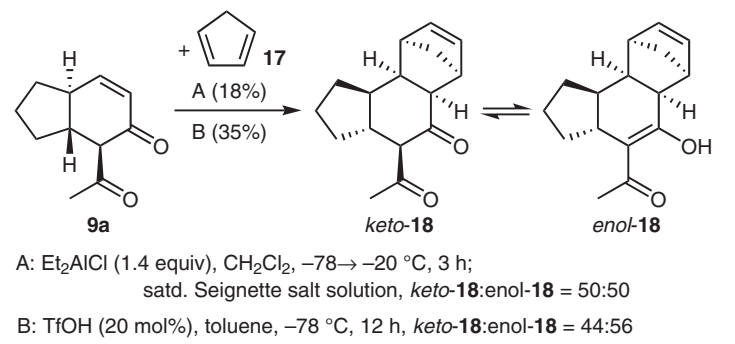

Scheme 4 Diels-Alder reaction of $\mathbf{9 a}$ and cyclopentadiene (17)

First, different Lewis or Brønsted acids and solvents were screened, but either decomposition or no conversion at all was observed (for details, see Schemes S2 and S3 in $\mathrm{SI})$. However, the desired tetracycle $\mathbf{1 8}$ (50:50) could be isolated in $18 \%$ when employing 1.4 equivalents of $\mathrm{Et}_{2} \mathrm{AlCl}$ in $\mathrm{CH}_{2} \mathrm{Cl}_{2}$ at $-78{ }^{\circ} \mathrm{C}$ and warming the mixture to $-20{ }^{\circ} \mathrm{C}$ over 3 hours followed by hydrolysis with aqueous Seignette salt solution (Method A). Both ${ }^{1} \mathrm{H}$ NMR spectra and GC-MS chromatograms indicated that the crude product contained cyclopentadiene-derived oligomer. ${ }^{48,49}$ Following Method B, that is, use of trifluoromethanesulfonic acid (20 mol\%) in toluene at $-78{ }^{\circ} \mathrm{C}$ and quenching after 12 hours with $\mathrm{NEt}_{3}$ and aqueous workup, provided the tetracycle $\mathbf{1 8}$ in $35 \%$ (ratio 44:56). Initially, we surmised that the two sets of signals visible in the ${ }^{1} \mathrm{H}$ NMR spectrum of $\mathbf{1 8}$ might be caused by the two diastereomers. But HMBC measurements and 
comparison with known 1,3-dicarbonyl derivatives ${ }^{50}$ revealed the presence of keto- and enol-tautomer keto-18, enol-18, whose stereochemical structure was deduced from 2D NOESY experiments (Figures S3 and S4 in SI). It should be emphasized that enol-18 stereoselectively equilibrates to keto-18 with the $4 R$-configuration of the acetyl-carrying carbon atom, while the corresponding epimer with $4 S$-configuration was not detected. Presumably, the diastereofacial preference of the protonation step is governed by formation of the thermodynamically more stable (4R)-keto-18 with an equatorial acetyl moiety as compared to the (4S)-keto-18 with axial acetyl group. A thermodynamically driven tautomerization as the final step was also proposed by Carrillo and Vicario in the synthesis of trans-decalines. ${ }^{51}$ Furthermore, upon prolonged storage of tetracycle 18 in $\mathrm{CDCl}_{3}$ the equilibrium shifted from $(4 R)$-keto-18/enol-18 $=44: 56$ to 57:43.

We performed first density functional theory (DFT)based calculations to elucidate the relative thermodynamic stabilities of (4R)-keto-18 and (4S)-keto-18 (Figure 3). Comparing the two configurations we found that (4R)-keto-18 to be $85 \mathrm{~kJ} / \mathrm{mol}$ more stable than (4S)-keto-18. This result is consistent with the observed diastereofacial preference of (4R)-keto-18 due to a thermodynamically driven tautomerization.
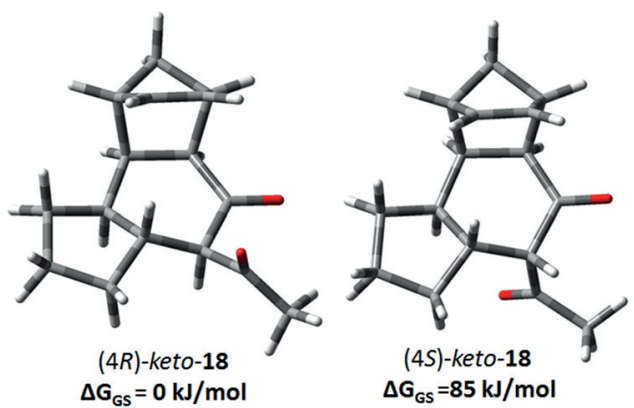

Figure 3 Optimized minimum structures of (4R)-keto-18 and (4S)-keto-18 and their associated relative stabilities. $\Delta \mathrm{G}_{\mathrm{GS}}$ is the electronic energy corrected for the free energy at $300 \mathrm{~K}$ in the ground state. The DFT calculations were performed at the B3LYP/AUG-cc-pVTZ level of theory. Light gray: $\mathrm{H}$; dark gray: C; red: $\mathrm{O}$.

In conclusion, we have demonstrated the first organocatalytic Michael addition of acetylacetone (12a) and ethyl acetoacetate (12b) with 1-cyclopentene-1-carbaldehyde (11) in the presence of Jørgensen-Hayashi catalyst 13c providing highly oxo-functionalized cyclopentane derivatives 10 in good yields with high enantioselectivity up to 99:1 on gram scale with a catalyst loading of only $2 \mathrm{~mol} \%$. Acid-mediated intramolecular aldol condensation converted $\mathbf{1 0}$ into the corresponding trans-4-acylhexahydro-5H-inden-5ones 9 in moderate to good yields with high diastereoselectivities (up to 94:6). Hexahydroindenone 9a was submitted to a $[4+2]$ cycloaddition with cyclopentadiene $(\mathbf{1 7})$ yielding the tetracyclic tautomers (4R)-keto-18/enol-18. Surpris- ingly, despite the keto/enol tautomeric equilibrium the $4 R$ configuration of the exocyclic acetyl moiety was maintained due to thermodynamic control of the scaffold supported by DFT calculations. Thus, a high degree of molecular complexity (4 rings, 7 stereogenic centers) was obtained in only four steps [including the synthesis of 1-cyclopentene-1-carbaldehyde (11) from commercially available 1,2-cyclohexanediol $^{39}$ ]. These results not only expand the scope of the Jørgensen-Hayashi catalyst, but also demonstrate the access to polycyclic derivatives in a few redox-economic steps via synthetically valuable, enantioenriched hexahydroindenones without the use of protecting groups, which paves the way for their application in syntheses of complex target molecules. ${ }^{52}$

${ }^{1} \mathrm{H}$ and ${ }^{13} \mathrm{C}$ NMR were recorded on a Bruker Avance 300, an Ascend 400, an Avance 500, and a Bruker Avance 700 spectrometer. Chemical shifts are reported in ppm relative to $\mathrm{CDCl}_{3}$ as internal standard. Assignment of NMR spectra was based on correlation spectroscopy (COSY, HSQC, HMBC, and NOESY spectra). Mass spectra and GC-MS were recorded on a Bruker Daltonics micro-TOF-Q instument, a Varian MAT 711 spectrometer, and an Agilent 6890N Network GC system gas-phase chromatograph equipped with a 5973 Network Mass Selective detector, respectively. FTIR spectra were recorded on a Bruker Vektor 22 spectrometer equipped with a MKII Golden Gate Single Refection Diamand. GC was performed on a Thermo Scientic Trace 1300 gas-phase chromatograph with fused silica column $(30 \mathrm{~m} \times 0.32 \mathrm{~mm}$, $0.25 \mu \mathrm{m}$ thickness, TG-35 MS phase) (achiral) and on a Fisons Instrument HRGC Mega 2 series 8565 with a fused silica column $(25 \mathrm{~m} \times$ $0.25 \mathrm{~mm}$, thickness $0.25 \mu \mathrm{m}, \mathrm{CP}$ Chirasil DEX CB phase) (chiral). HPLC was performed on a Shimadzu HPLC system on a MZ-Analytical Kromasil 100 Silica $5 \mu \mathrm{m}$ column $(250 \times 4.6 \mathrm{~mm})$, on a Chiracel OD-H or on a Chiracel OJ-H column. Optical rotation was performed on a PerkinElmer 241 polarimeter (cuvette $1=0.1 \mathrm{~m}$ ). The numbering system shown in Figure 4 was used only for NMR assignment.

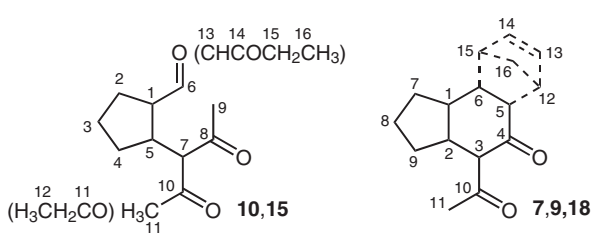

Figure 4 Numbering system for NMR assignment

\section{(1R,2R)-2-(1-Acetyl-2-oxopropyl)cyclopentanecarbaldehyde $(\mathbf{1 0 a})^{34}$}

Method A: A solution of 13a (111 mg, $1.56 \mathrm{mmol}, 0.5$ equiv), 12a (312 mg, $3.12 \mathrm{mmol}, 1$ equiv) and $11\left(\mathbf{1 1} / \mathrm{Et}_{2} \mathrm{O}=80: 20,400 \mathrm{mg}\right.$, $3.12 \mathrm{mmol}, 1$ equiv) in EtOH $(8.0 \mathrm{~mL})$ was stirred for $15 \mathrm{~h}$ at r.t. The solvent was removed under reduced pressure and the residue purified by chromatography on $\mathrm{SiO}_{2}$ to give $10 \mathrm{a}$ as a yellow oil; yield: $9.0 \mathrm{mg}$ (96.8 $\mu \mathrm{mol}, 3 \%)$; d.r. = 50:50 ( $\left.{ }^{1} \mathrm{H} \mathrm{NMR}, 6-\mathrm{H}\right)$.

Method B: To a solution of 12a (2.12 g, $21.2 \mathrm{mmol}, 2$ equiv) and $\mathbf{1 3 c}$ (69.1 mg, $212 \mu \mathrm{mol}, 0.02$ equiv) in cold toluene $(26 \mathrm{~mL})$ at $0{ }^{\circ} \mathrm{C}$ was added $\mathbf{1 1}\left(\mathbf{1 1} / \mathrm{Et}_{2} \mathrm{O}=80: 20,1.36 \mathrm{~g}, 10.6 \mathrm{mmol}, 1\right.$ equiv $)$, and the reaction mixture was warmed to r.t. After stirring for $48 \mathrm{~h}$, the solvent was removed under reduced pressure. ${ }^{34}$ The residue was purified ei- 
ther by filtration over a silica pad with hexanes/EtOAc (2:1) to give 10a as an orange oil; yield: $1.66 \mathrm{~g}(7.59 \mathrm{mmol}, 72 \%) ; 88 \%$ purity by $\mathrm{GC}_{\text {achiral }}$ or by flash chromatography on $\mathrm{SiO}_{2}$ with hexanes/EtOAc [gradient $5: 1 \rightarrow 2: 1 ; R_{f}=0.16$ (hexanes/EtOAc $5: 1$ )] to give 10a $(40 \%$ ); $>99 \%$ purity by $\mathrm{GC}_{\text {achiral }} ;[\alpha]_{D}{ }^{20}-129.1\left(c=0.77, \mathrm{CHCl}_{3}, e e=98 \%\right)$.

FT-IR: $2956(w), 2871(w), 1716(s), 1694(s), 1420(w), 1357(w)$, $1239(s), 1185(w), 1143(w), 955(w), 619(w), 582(w), 531 \mathrm{~cm}^{-1}$ (w).

${ }^{1} \mathrm{H}$ NMR $\left(500 \mathrm{MHz}, \mathrm{CDCl}_{3}\right): \delta=1.24$ (dddd, $J=12.8,8.3,8.3,8.2 \mathrm{~Hz}, 1$ $\mathrm{H}, 1 \times 4-\mathrm{H}), 1.48-1.59(\mathrm{~m}, 1 \mathrm{H}, 1 \times 3-\mathrm{H}), 1.68$ (dddd, $J=12.8,11.0,7.1$, $5.3 \mathrm{~Hz}, 1 \mathrm{H}, 1 \times 3-\mathrm{H}), 1.80-1.87(\mathrm{~m}, 3 \mathrm{H}, 1 \times 4-\mathrm{H}, 2-\mathrm{H}), 2.13(\mathrm{~s}, 3 \mathrm{H}, 11-$ H), 2.16 (s, $3 \mathrm{H}, 9-\mathrm{H}), 2.33$ (dddd, $J=9.7,8.3,6.9 \mathrm{~Hz}, 3.0 \mathrm{~Hz}, 1 \mathrm{H}, 1-\mathrm{H}$ ), 2.95 (dddd, $J=10.3,9.7,9.7,8.2 \mathrm{~Hz}, 1 \mathrm{H}, 5-\mathrm{H}), 3.62$ (d, $J=10.3 \mathrm{~Hz}, 1 \mathrm{H}$, 7-H), $9.53(\mathrm{~d}, J=3.0 \mathrm{~Hz}, 1 \mathrm{H}, 6-\mathrm{H})$.

${ }^{13} \mathrm{C}$ NMR $\left(126 \mathrm{MHz}, \mathrm{CDCl}_{3}\right): \delta=24.7(\mathrm{C}-3), 27.1(\mathrm{C}-2), 29.2(\mathrm{C}-9)$, 30.0 (C-11), 30.9 (C-4), 39.1 (C-5), 55.9 (C-1), 74.1 (C-7), 202.4 (C-6), $203.3(\mathrm{C}-10), 203.6(\mathrm{C}-8)$.

MS (ESI): $m / z=235\left[\mathrm{M}+\mathrm{K}^{+}\right], 219\left[\mathrm{M}+\mathrm{Na}^{+}\right]$.

HRMS (ESI): $m / z$ [M $+\mathrm{Na}^{+}$calcd for $\mathrm{C}_{11} \mathrm{H}_{16} \mathrm{O}_{3} \mathrm{Na}^{+}:$219.0992; found: 219.0973.

\section{Ethyl 2-[(1R,2R)-2-Formylcyclopentyl]-3-oxobutanoate (10b)}

Method A: To a solution of 13a (555 mg, $7.80 \mathrm{mmol}, 0.5$ equiv) and 12b (2.07 mg, $15.9 \mathrm{mmol}, 1.02$ equiv) in toluene $(40 \mathrm{~mL})$ was added $11\left(11 / \mathrm{Et}_{2} \mathrm{O}=80: 20,2.00 \mathrm{~g}, 15.6 \mathrm{mmol}, 1\right.$ equiv) and the reaction mixture was stirred for $60 \mathrm{~h}$ at r.t. The solvent was removed under reduced pressure and the residue purified by flash chromatography on $\mathrm{SiO}_{2}$ with hexanes/EtOAc (5:1) to give $10 \mathrm{~b}$ as a yellow oil; yield: $1.24 \mathrm{~g}$ (3.84 mmol, 25\%); 70\% purity by ${ }^{1} \mathrm{H}$ NMR analysis.

Method B: A solution of $\mathbf{1 3 c}(23.7 \mathrm{mg}, 72.8 \mu \mathrm{mol}, 0.02$ equiv) and $\mathbf{1 2 b}$ (237 mg, $1.82 \mathrm{mmol}, 1$ equiv) in toluene $(4.5 \mathrm{~mL})$ was cooled to $0{ }^{\circ} \mathrm{C}$ and 11 (11/ $\mathrm{Et}_{2} \mathrm{O}=75: 25,250 \mathrm{mg}, 1.82 \mathrm{mmol}, 1$ equiv) was added. The reaction mixture was stirred for $24 \mathrm{~h}$ at r.t. The solvent was removed under reduced pressure and the residue was filtered over a silica pad with hexanes/EtOAc (2:1) to give $\mathbf{1 0 b}$ as a colorless oil; yield: $373 \mathrm{mg}$ $(1.65 \mathrm{mmol}, 91 \%) ; \mathrm{D} 1: \mathrm{D} 2=50: 50$ by GC achiral $;[\alpha]_{\mathrm{D}}{ }^{20}-51.3(c=0.64$, $\left.\mathrm{CHCl}_{3}\right)$; d.r. $=50: 50$.

FT-IR: $3437(w), 2958(w), 2873(w), 2725(w), 1716(s), 1449(w)$, $1360(w), \quad 1246(w), \quad 1186(w), \quad 1148(w), \quad 1095(w)$, $1023(w), 857(w), 540 \mathrm{~cm}^{-1}(w)$.

${ }^{1} \mathrm{H}$ NMR $\left(500 \mathrm{MHz}, \mathrm{CDCl}_{3}\right.$ ): $\delta$ (signals of both diastereomers, arbitrarily denoted $)=1.25\left(\mathrm{t}, J=7.1 \mathrm{~Hz}, 3 \mathrm{H}, \mathrm{OCH}_{2} \mathrm{CH}_{3, \mathrm{D} 2}\right), 1.28(\mathrm{t}, J=7.1 \mathrm{~Hz}, 3$ $\left.\mathrm{H}, \mathrm{OCH}_{2} \mathrm{CH}_{3, \mathrm{D} 1}\right), 1.24-1.34\left(\mathrm{~m}, 1 \mathrm{H}, 1 \times 4-\mathrm{H}_{\mathrm{D} 2}\right), 1.40$ (dddd, $J=12.6,8.6$, 8.6, 7.8 Hz, $\left.1 \mathrm{H}, 1 \times 4-\mathrm{H}_{\mathrm{D} 1}\right), 1.52-1.62\left(\mathrm{~m}, 2 \mathrm{H}, 1 \times 3-\mathrm{H}_{\mathrm{D} 1}, 1 \times 3-\mathrm{H}_{\mathrm{D} 2}\right)$, 1.66-1.75 (m, $\left.2 \mathrm{H}, 1 \times 3-\mathrm{H}_{\mathrm{D} 1}, 1 \times 3-\mathrm{H}_{\mathrm{D} 2}\right), 1.83-1.89\left(\mathrm{~m}, 4 \mathrm{H}, 2-\mathrm{H}_{\mathrm{D} 1}, 2-\right.$ $\mathrm{H}_{\mathrm{D} 2}$ ), 1.93 (dddd, $\left.J=12.6,7.8,7.8,4.7 \mathrm{~Hz}, 1 \mathrm{H}, 1 \times 4-\mathrm{H}_{\mathrm{D} 1}\right), 1.93$ (dddd, $\left.J=12.6,7.8,7.8,4.7 \mathrm{~Hz}, 1 \mathrm{H}, 1 \times 4-\mathrm{H}_{\mathrm{D} 2}\right), 2.21\left(\mathrm{~s}, 3 \mathrm{H}, 9-\mathrm{H}_{\mathrm{D} 2}\right), 2.25(\mathrm{~s}, 3$ $\mathrm{H}, 9-\mathrm{H}_{\mathrm{D} 1}$ ), 2.45 (dddd, $J=7.6,7.6,7.6,2.8 \mathrm{~Hz}, 1 \mathrm{H}, 1-\mathrm{H}_{\mathrm{D} 1}$ ), 2.57 (dddd, $\left.J=8.8,7.0,7.0,3.0 \mathrm{~Hz}, 1 \mathrm{H}, 1-\mathrm{H}_{\mathrm{D} 2}\right), 2.92$ (dddd, $J=9.5,8.8,7.8,7.8 \mathrm{~Hz}$, $\left.1 \mathrm{H}, 5-\mathrm{H}_{\mathrm{D} 2}\right), 2.92$ (dddd, $\left.J=9.7,8.3,7.8,7.8 \mathrm{~Hz}, 1 \mathrm{H}, 5-\mathrm{H}_{\mathrm{D} 1}\right), 3.43(\mathrm{~d}$, $\left.J=9.5 \mathrm{~Hz}, 1 \mathrm{H}, 7-\mathrm{H}_{\mathrm{D} 2}\right), 3.44\left(\mathrm{~d}, J=9.7 \mathrm{~Hz}, 1 \mathrm{H}, 7-\mathrm{H}_{\mathrm{D} 1}\right), 4.15(\mathrm{qd}, J=7.1$, $1.2 \mathrm{~Hz}, 2 \mathrm{H}, \mathrm{OCH}_{2} \mathrm{CH}_{3, \mathrm{D} 2}$ ), 4.21 (qd, $J=7.2,1.0 \mathrm{~Hz}, 2 \mathrm{H}, \mathrm{OCH}_{2} \mathrm{CH}_{3, \mathrm{D} 1}$ ), $9.58\left(\mathrm{~d}, J=3.0 \mathrm{~Hz}, 1 \mathrm{H}, 6-\mathrm{H}_{\mathrm{D} 2}\right), 9.60\left(\mathrm{~d}, J=2.8 \mathrm{~Hz}, 1 \mathrm{H}, 6-\mathrm{H}_{\mathrm{D} 1}\right)$.

${ }^{13} \mathrm{C}$ NMR $\left(126 \mathrm{MHz}, \mathrm{CDCl}_{3}\right): \delta=14.0\left(\mathrm{OCH}_{2} \mathrm{CH}_{3, \mathrm{D} 2}\right), 14.1\left(\mathrm{OCH}_{2} \mathrm{CH}_{3, \mathrm{D} 1}\right)$, $24.8\left(C-3_{D 1}\right), 25.0\left(C-3_{D 2}\right), \quad 27.3\left(C-2_{D 1}\right), 27.4\left(C-2_{D 2}\right), 29.3\left(C-9_{D 2}\right)$, $29.3\left(\mathrm{C}-9_{\mathrm{D} 1}\right), 30.9\left(\mathrm{C}-4_{\mathrm{D} 1}\right), 31.4\left(\mathrm{C}-4_{\mathrm{D} 2}\right), 38.8\left(\mathrm{C}-5_{\mathrm{D} 2}\right), 39.1\left(\mathrm{C}-5_{\mathrm{D} 1}\right), 55.4$ $\left(\mathrm{C}-1_{\mathrm{D} 2}\right), 55.7\left(\mathrm{C}-1_{\mathrm{D} 1}\right), 61.6\left(\mathrm{OCH}_{2} \mathrm{CH}_{3, \mathrm{D} 1}\right), 61.7\left(\mathrm{OCH}_{2} \mathrm{CH}_{3, \mathrm{D} 2}\right), 64.3(\mathrm{C}-$ $\left.7_{\mathrm{D} 1}\right), 64.4\left(\mathrm{C}-7_{\mathrm{D} 2}\right), 168.8\left(\mathrm{C}-10_{\mathrm{D} 1}\right), 168.8\left(\mathrm{C}-10_{\mathrm{D} 2}\right), 202.2\left(\mathrm{C}-8_{\mathrm{D} 1}\right), 202.5$ $\left(\mathrm{C}-8_{\mathrm{D} 2}\right), 202.5\left(\mathrm{C}-6_{\mathrm{D} 2}\right), 202.6\left(\mathrm{C}-6_{\mathrm{D} 1}\right)$.
MS (ESI): $m / z=249\left[\mathrm{M}+\mathrm{Na}^{+}\right], 209,184,149,131$.

HRMS (ESI): $m / z\left[\mathrm{M}+\mathrm{Na}^{+}\right]$calcd for $\mathrm{C}_{12} \mathrm{H}_{18} \mathrm{O}_{4} \mathrm{Na}^{+}: 249.1097$; found: 249.1071

\section{Ethyl (2E)-3-\{(1S,2R)-2-[1-(Ethoxycarbonyl)-2-oxopropyl]cyclo- pentyl\}acrylate (15)}

Method A: A solution of $\mathbf{1 2 b}$ ( $379 \mathrm{mg}, 2.91 \mathrm{mmol}, 1$ equiv), 13a (104 mg, $1.48 \mathrm{mmol}, 0.5$ equiv), and 11 (11/ $\mathrm{Et}_{2} \mathrm{O}=87: 13,400 \mathrm{mg}$, $2.91 \mathrm{mmol}, 1$ equiv) in toluene $(8.0 \mathrm{~mL})$ was stirred for $24 \mathrm{~h}$ at r.t. After filtration over a silica pad with hexanes/EtOAc (2:1), the filtrate was concentrated, and the residue dissolved in toluene $(15 \mathrm{~mL})$. Phosphonium bromide 14 (1.25 g, $2.91 \mathrm{mmol}, 1$ equiv) and $\mathrm{NEt}_{3}$ (442 mg, $4.37 \mathrm{mmol}, 1.5$ equiv) were added, and the reaction mixture was stirred for $22 \mathrm{~h}$ at r.t. Then it was washed with $\mathrm{H}_{2} \mathrm{O}(10 \mathrm{~mL})$, dried $\left(\mathrm{MgSO}_{4}\right)$, and the solvent removed under reduced pressure. The residue was purified by chromatography on $\mathrm{SiO}_{2}$ with hexanes/EtOAc (gradient 15:1 $\rightarrow$ 10:1) to give rac-15 as a yellow oil; yield: $287 \mathrm{mg}$ (968 $\mu \mathrm{mol}, 33 \%)$; d.r. $47: 40: 8: 5$ by $\mathrm{GC}_{\text {achiral }}$.

Method $B$ : A solution of $\mathbf{1 1}\left(\mathbf{1 1} / \mathrm{Et}_{2} \mathrm{O}=87: 12,500 \mathrm{mg}, 4.42 \mathrm{mmol}\right.$, 1 equiv), 12b (575 mg, $4.42 \mathrm{mmol}, 1$ equiv), and $13 \mathbf{c}(28.8 \mathrm{mg}$, $88.4 \mu \mathrm{mol}, 0.02$ equiv) in toluene $(10 \mathrm{~mL})$ was stirred for $72 \mathrm{~h}$ at r.t. After the addition of phosphonium bromide $14(1.99 \mathrm{~g}, 4.64 \mathrm{mmol}$, 1.05 equiv $)$ and $\mathrm{NEt}_{3}(0.7 \mathrm{ml}, 671 \mathrm{mg}, 6.63 \mathrm{mmol}, 1.5$ equiv $)$, the reaction mixture was stirred for $8 \mathrm{~h}$ at r.t. Then $\mathrm{H}_{2} \mathrm{O}(20 \mathrm{~mL})$ was added and the mixture extracted with $\mathrm{CH}_{2} \mathrm{Cl}_{2}(3 \times 20 \mathrm{~mL})$. The combined organic layers were dried $\left(\mathrm{MgSO}_{4}\right)$ and the solvent was removed under reduced pressure. The residue was purified by chromatography on $\mathrm{SiO}_{2}$ with hexanes/EtOAc [gradient 30:1 $\rightarrow$ 10:1, $R_{f}=0.28$, hexanes/EtOAc (10:1)] to give $\mathbf{1 5}$ as a colorless oil; yield: $351 \mathrm{mg}$ $(1.18 \mathrm{mmol}, 27 \%) ; \mathrm{D} 1: \mathrm{D} 2=55: 45$ by $\mathrm{GC}_{\text {achiral }} ;[\alpha]_{\mathrm{D}}{ }^{20}-52.6(c=0.54$, $\left.\mathrm{CHCl}_{3}\right)$; d.r. $=55: 45$.

FT-IR: $2956(w), 2871(w), 1710(s), 1651(w), 1448(w), 1368(w)$, $1306(w), 1264(w), 1227(w), 1194(w), 1146(s), 1096(w), 1033(w)$, $984(w), 914(w), 862(w), 810(w), 730(s), 647(w), 540 \mathrm{~cm}^{-1}(w)$.

${ }^{1} \mathrm{H}$ NMR $\left(500 \mathrm{MHz}, \mathrm{CDCl}_{3}\right): \delta$ (signals of both diastereomers, arbitrarily denoted $)=1.16\left(\mathrm{t}, J=7.2 \mathrm{~Hz}, 3 \mathrm{H}, 12-\mathrm{H}_{\mathrm{D} 1}\right), 1.18-1.23(\mathrm{~m}, 11 \mathrm{H}$, $\left.1 \times 4-\mathrm{H}_{\mathrm{D} 1}, 1 \times 4-\mathrm{H}_{\mathrm{D} 2}, 12-\mathrm{H}_{\mathrm{D} 2}, 16-\mathrm{H}_{\mathrm{D} 1}, 16-\mathrm{H}_{\mathrm{D} 2}\right), 1.39-1.50(\mathrm{~m}, 2 \mathrm{H}, 1 \times 2-$ $\left.\mathrm{H}_{\mathrm{D} 1}, 1 \times 2-\mathrm{H}_{\mathrm{D} 2}\right), 1.54-1.66\left(\mathrm{~m}, 4 \mathrm{H}, 3-\mathrm{H}_{\mathrm{D} 1}, 3-\mathrm{H}_{\mathrm{D} 2}\right), 1.76-1.84(\mathrm{~m}, 2 \mathrm{H}$, $\left.1 \times 2-\mathrm{H}_{\mathrm{D} 1}, 1 \times 2-\mathrm{H}_{\mathrm{D} 2}\right), 1.84-1.93\left(\mathrm{~m}, 2 \mathrm{H}, 1 \times 4-\mathrm{H}_{\mathrm{D} 1}, 1 \times 4-\mathrm{H}_{\mathrm{D} 2}\right), 2.09(\mathrm{~s}$, $\left.3 \mathrm{H}, 9-\mathrm{H}_{\mathrm{D} 2}\right), 2.13\left(\mathrm{~s}, 3 \mathrm{H}, 9-\mathrm{H}_{\mathrm{D} 2}\right), 2.27-2.34\left(\mathrm{~m}, 3 \mathrm{H}, 1-\mathrm{H}_{\mathrm{D} 1}, 1-\mathrm{H}_{\mathrm{D} 2}, 5-\right.$ $\left.\mathrm{H}_{\mathrm{D} 2}\right), 2.34-2.44\left(\mathrm{~m}, 1 \mathrm{H}, 5-\mathrm{H}_{\mathrm{D} 1}\right), 3.26\left(\mathrm{~d}, J=9.5 \mathrm{~Hz}, 1 \mathrm{H}, 7-\mathrm{H}_{\mathrm{D} 1}\right), 3.34(\mathrm{~d}$, $\left.J=6.9 \mathrm{~Hz}, 1 \mathrm{H}, 7-\mathrm{H}_{\mathrm{D} 2}\right), 3.93-4.05\left(\mathrm{~m}, 2 \mathrm{H}, 11-\mathrm{H}_{\mathrm{D} 1}\right), 4.05-4.15(\mathrm{~m}, 6 \mathrm{H}$, $\left.11-\mathrm{H}_{\mathrm{D} 2}, 15-\mathrm{H}_{\mathrm{D} 1}, 15-\mathrm{H}_{\mathrm{D} 2}\right), 5.66\left(\mathrm{~d}, J=15.5 \mathrm{~Hz}, 1 \mathrm{H}, 13-\mathrm{H}_{\mathrm{D} 1}\right), 5.69(\mathrm{~d}, J=$ $\left.15.2 \mathrm{~Hz}, 1 \mathrm{H}, 13-\mathrm{H}_{\mathrm{D} 2}\right), 6.69\left(\mathrm{dd}, J=15.5,3.1 \mathrm{~Hz}, 1 \mathrm{H}, 6-\mathrm{H}_{\mathrm{D} 1}\right) 6.71(\mathrm{dd}, J=$ 15.2, 3.3 Hz, $\left.1 \mathrm{H}, 6-\mathrm{H}_{\mathrm{D} 2}\right)$.

${ }^{13} \mathrm{C}$ NMR $\left(126 \mathrm{MHz}, \mathrm{CDCl}_{3}\right): \delta=13.8\left(\mathrm{C}-12_{\mathrm{D} 1}\right), 14.1\left(\mathrm{C}-12_{\mathrm{D} 2}\right), 14.2(\mathrm{C}-$ $\left.16_{\mathrm{D} 2}\right), 14.2\left(\mathrm{C}-16_{\mathrm{D} 1}\right), 23.7\left(\mathrm{C}-3_{\mathrm{D} 1}\right), 23.8\left(\mathrm{C}-3_{\mathrm{D} 2}\right), 29.0\left(\mathrm{C}-9_{\mathrm{D} 1}\right), 29.1(\mathrm{C}-$ $\left.9_{\mathrm{D} 2}\right), 29.4\left(\mathrm{C}-4_{\mathrm{D} 2}\right), 30.7\left(\mathrm{C}-4_{\mathrm{D} 1}\right), 32.6\left(\mathrm{C}-2_{\mathrm{D} 2}\right), 32.8\left(\mathrm{C}-2_{\mathrm{D} 1}\right), 44.2\left(\mathrm{C}-5_{\mathrm{D} 2}\right)$, $44.4\left(\mathrm{C}-5_{\mathrm{D} 1}\right), 46.7\left(\mathrm{C}-1_{\mathrm{D} 2}\right), 47.4\left(\mathrm{C}-1_{\mathrm{D} 1}\right), 60.1\left(\mathrm{C}-15_{\mathrm{D} 1}\right), 60.2\left(\mathrm{C}-15_{\mathrm{D} 2}\right)$, $61.2\left(\mathrm{C}-11_{\mathrm{D} 2}\right), 61.2\left(\mathrm{C}-11_{\mathrm{D} 1}\right), 62.6\left(\mathrm{C}-7_{\mathrm{D} 2}\right), 64.7\left(\mathrm{C}-7_{\mathrm{D} 1}\right), 120.7\left(\mathrm{C}-13_{\mathrm{D} 1}\right)$, $121.3\left(\mathrm{C}-13_{\mathrm{D} 2}\right), 151.2\left(\mathrm{C}-6_{\mathrm{D} 1}\right), 151.4\left(\mathrm{C}-6_{\mathrm{D} 2}\right), 166.3\left(\mathrm{C}-14_{\mathrm{D} 1}\right), 166.3(\mathrm{C}-$ $\left.14_{\mathrm{D} 2}\right), 168.5\left(\mathrm{C}-10_{\mathrm{D} 1}\right), 168.9\left(\mathrm{C}-10_{\mathrm{D} 2}\right), 202.1\left(\mathrm{C}-8_{\mathrm{D} 1}\right), 202.3\left(\mathrm{C}-8_{\mathrm{D} 2}\right)$.

MS (ESI): $m / z=319\left[\mathrm{M}+\mathrm{Na}^{+}\right], 297,251,233,205,177,121$.

HRMS (ESI): $m / z\left[\mathrm{M}+\mathrm{Na}^{+}\right]$calcd for $\mathrm{C}_{16} \mathrm{H}_{24} \mathrm{O}_{5} \mathrm{Na}^{+}$: 319.1516 ; found: 319.1516 .

\section{(3aS,7aR)-1,2,3,3a,4,7a-Hexahydro-5H-inden-5-one (7)}

To a solution of $(1 R, 2 R)-\mathbf{1 0 a}(530 \mathrm{mg}, 2.70 \mathrm{mmol}, 1$ equiv) in $\mathrm{MeOH}$ $(130 \mathrm{~mL})$ at $0{ }^{\circ} \mathrm{C}$ was added $\mathrm{KOH}(607 \mathrm{mg}, 10.8 \mathrm{mmol}, 4$ equiv), and the reaction mixture was stirred for $2.5 \mathrm{~h}$ at r.t. and then concentrated 
under reduced pressure. Sat. aq $\mathrm{NH}_{4} \mathrm{Cl}$ was added to the residue (under ice cooling), and the mixture was extracted with $\mathrm{CH}_{2} \mathrm{Cl}_{2}$ $(3 \times 30 \mathrm{~mL})$. The combined organic layers were dried $\left(\mathrm{MgSO}_{4}\right)$ and the solvent was removed under reduced pressure. To the yellow residue in anhyd $\mathrm{CH}_{2} \mathrm{Cl}_{2}(13 \mathrm{~mL})$ were added $\mathrm{NEt}_{3}(1.2 \mathrm{~mL}, 956 \mathrm{mg}, 9.45 \mathrm{mmol}$, 3.5 equiv) and DMAP ( $32.9 \mathrm{mg}, 270 \mu \mathrm{mol}, 0.1$ equiv) and the mixture was cooled to $0{ }^{\circ} \mathrm{C}$. Then $\mathrm{MsCl}$ (464 mg, $4.05 \mathrm{mmol}, 1.5$ equiv) was added dropwise and the mixture stirred for $17 \mathrm{~h}$ at r.t. After the addition of $\mathrm{H}_{2} \mathrm{O}(20 \mathrm{~mL})$, the mixture was extracted with $\mathrm{CH}_{2} \mathrm{Cl}_{2}$ $(3 \times 25 \mathrm{~mL})$. The combined organic extracts were dried $\left(\mathrm{MgSO}_{4}\right)$ and the solvent was removed under reduced pressure. The residue was chromatographed on $\mathrm{SiO}_{2}$ with hexanes/EtOAc (20:1) to give 7 as a yellow oil; yield: $184 \mathrm{mg}(1.35 \mathrm{mmol}, 50 \%) ; \quad R_{f}=0.35$ (hexanes/EtOAc 10:1).

FT-IR: $3025(w), 2951(w), 2871(w), 1736(w), 1673(s), 1604(w)$, $1456(w), 1415(w), 1386(w), 1356(w), 1308(w), 1244(w)$, $1199(w), 1152(w), 1117(w), 1083(w), 1043(w), 895(w), 817(w)$, $756(w), 556(w), 510(w), 452 \mathrm{~cm}^{-1}(w)$.

${ }^{1} \mathrm{H}$ NMR $\left(500 \mathrm{MHz}, \mathrm{CDCl}_{3}\right): \delta=1.26-1.36(\mathrm{~m}, 2 \mathrm{H}, 1 \times 7-\mathrm{H}, 1 \times 9-\mathrm{H})$, 1.68-1.76 (m, 2 H, 8-H), 1.74-1.85 (m, 2 H, 2-H, $1 \times 9-\mathrm{H}), 1.95$ (dddd, $J=11.9,7.1,7.1,4.4 \mathrm{~Hz}, 1 \mathrm{H}, 1 \times 7-\mathrm{H}), 2.05-2.15(\mathrm{~m}, 1 \mathrm{H}, 1-\mathrm{H}), 2.09$ (dd, $J=16.7,13.6 \mathrm{~Hz}, 1 \mathrm{H}, 1 \times 3-\mathrm{H}), 2.68(\mathrm{dd}, J=16.7,3.0 \mathrm{~Hz}, 1 \mathrm{H}$, $1 \times 3-\mathrm{H}$ ), 5.91 (ddd, $J=9.9,2.9,1.0 \mathrm{~Hz}, 1 \mathrm{H}, 6-\mathrm{H}), 7.04$ (dd, $J=9.9$, $1.9 \mathrm{~Hz}, 1 \mathrm{H}, 5-\mathrm{H})$.

${ }^{13} \mathrm{C}$ NMR (126 MHz, $\mathrm{CDCl}_{3}$ ): $\delta=22.2$ (C-8), 28.4 (C-7), 30.2 (C-9), 44.7 (C-3), 44.8 (C-2), 45.0 (C-1), 130.3 (C-6), 152.6 (C-5), 201.0 (C-4).

MS (EI): $m / z(\%)=136(100)\left[\mathrm{M}^{+}\right], 81$ (75), 68 (80), 55 (45).

HRMS (EI): $m / z$ [M+ $\mathrm{M}^{+}$calcd for $\mathrm{C}_{9} \mathrm{H}_{12} \mathrm{O}^{+}$: 136.0888 ; found: 136.0887 .

\section{(3aR,4R,7aS)-4-Acetyl-1,2,3,3a,4,7a-hexahydro-5H-inden-5-one (9a)}

A solution of $(1 R, 2 R)-\mathbf{1 0 a}(100 \mathrm{mg}, 509 \mu \mathrm{mol}, 1$ equiv) and CSA (118 mg, $509 \mu \mathrm{mol}, 1$ equiv) in toluene $(17 \mathrm{~mL}$ ) was heated for $65 \mathrm{~h}$ under reflux. After cooling to r.t., the solution was washed with sat. aq $\mathrm{NaHCO}_{3}$ and the solvent was removed under reduced pressure. The residue was purified by chromatography on $\mathrm{SiO}_{2}$ with hexanes/EtOAc (30:1) to give 9a as a yellow oil; yield: $66.0 \mathrm{mg}$ (370 $\mu \mathrm{mol}, 73 \%$ ); d.r. $94: 6$. Repeated crystallization from hexane $(0.5 \mathrm{~mL})$ at $-20{ }^{\circ} \mathrm{C}$ gave optically pure $9 \mathbf{9 a} ; R_{f}=0.39$ (hexanes/EtOAc 5:1); $[\alpha]_{D}{ }^{20}-6.4(c=0.63$, $\mathrm{CHCl}_{3}$ ).

FT-IR: $3025(w), 2958(w), 2872(w), 1713(s), 1660(s), 1603(w)$, $1454(w), 1421(w), 1385(w), 1353(w), 1306(w), 1285(w)$, $1259(w), \quad 1224(w), \quad 1175(w), 1140(w), \quad 1079(w), 1048(w)$, $1021(w), 970(w), 936(w), 895(w), 846(w), 775(w), 657(w)$, $585(w), 534(w), 508(w), 460 \mathrm{~cm}^{-1}(w)$.

${ }^{1} \mathrm{H} \mathrm{NMR}\left(500 \mathrm{MHz}, \mathrm{CDCl}_{3}\right): \delta=1.28$ (dddd, $J=11.4,9.7,9.7,8.3 \mathrm{~Hz}, 1$ $\mathrm{H}, 1 \times 9-\mathrm{H}), 1.41$ (dddd, $J=12.2,10.1,10.1,8.6 \mathrm{~Hz}, 1 \mathrm{H}, 1 \times 7-\mathrm{H}), 1.76-$ $1.83(\mathrm{~m}, 2 \mathrm{H}, 8-\mathrm{H}), 1.84-1.91(\mathrm{~m}, 1 \mathrm{H}, 1 \times 9-\mathrm{H}), 2.04$ (dddd, $J=11.4$, 7.2, 7.2, $3.9 \mathrm{~Hz}, 1 \mathrm{H}, 1 \times 7-\mathrm{H}$ ), 2.15 (dddd, $J=12.9,11.4,6.2,6.2 \mathrm{~Hz}, 1$ $\mathrm{H}, 2-\mathrm{H}), 2.27(\mathrm{~s}, 3 \mathrm{H}, 11-\mathrm{H}), 2.23-2.32(\mathrm{~m}, 1 \mathrm{H}, 1-\mathrm{H}), 3.27$ (d, $J=12.9 \mathrm{~Hz}, 1 \mathrm{H}, 3-\mathrm{H}$ ), 5.98 (dd, $J=9.8,2.9 \mathrm{~Hz}, 1 \mathrm{H}, 6-\mathrm{H}$ ), 7.13 (dd, $J=9.8,1.7 \mathrm{~Hz}, 1 \mathrm{H}, 5-\mathrm{H})$.

${ }^{13} \mathrm{C}$ NMR (126 MHz, CDCl 3 ): $\delta=22.0$ (C-8), 28.2 (C-7), 28.7 (C-9), 30.9 (C-11), 44.2 (C-1), 46.2 (C-2), 67.5 (C-3), 129.8 (C-6), 152.9 (C-5), 196.7 (C-4), 205.7 (C-10).

MS (ESI): $m / z=201\left[\mathrm{M}+\mathrm{Na}^{+}\right], 179\left[\mathrm{M}+\mathrm{H}^{+}\right], 161,149,137,119$.

HRMS (ESI): $m / z\left[\mathrm{M}+\mathrm{H}^{+}\right]$calcd for $\mathrm{C}_{11} \mathrm{H}_{15} \mathrm{O}_{2}{ }^{+}: 179.1081$; found: 179.1067.

\section{Ethyl (3aR,4S,7aS)-5-0xo-2,3,3a,4,5,7a-hexahydro-1H-indene-4- carboxylate (9b)}

From rac-10b: A solution of rac-10b $(1.24 \mathrm{~g}, 70 \%$ purity, $3.84 \mathrm{mmol}$, 1 equiv) and CSA ( $445 \mathrm{mg}, 1.92 \mathrm{mmol}, 0.5$ equiv) in toluene $(40 \mathrm{~mL})$ was heated under reflux (Dean-Stark conditions). After cooling to r.t., the solution was washed with sat. aq $\mathrm{NaHCO}_{3}(20 \mathrm{~mL})$, dried $\left(\mathrm{MgSO}_{4}\right)$, and the solvent removed under reduced pressure. The residue was purified by chromatography on $\mathrm{SiO}_{2}$ with hexanes/EtOAc (gradient $15: 1 \rightarrow 10: 1)$ to give $\mathbf{9 b}$ as a yellow oil; yield: $237 \mathrm{mg}(30 \%)$; d.r. 83:17.

From enantioenriched 10b: A solution of (3aR,4S,7aS)10b:(3aR,4R,7aS)-10b (86:14) (282 mg, $1.25 \mathrm{mmol}, 1$ equiv) and CSA ( $144 \mathrm{mg}, 623 \mu \mathrm{mol}, 0.5$ equiv) in toluene $(40 \mathrm{~mL}$ ) was heated for $2 \mathrm{~h}$ under reflux. After cooling to r.t., the solution was washed with sat. aq $\mathrm{NaHCO}_{3}(30 \mathrm{~mL})$, dried $\left(\mathrm{MgSO}_{4}\right)$, and the solvent removed under reduced pressure. The residue was purified by chromatography on $\mathrm{SiO}_{2}$ with hexanes/EtOAc (30:1) to give $\mathbf{9 b}$ as a yellow oil; yield: $55.0 \mathrm{mg}$ ( $264 \mu \mathrm{mol}, 35 \%$ ). The product was further purified by crystallization from pentane $(1.0 \mathrm{~mL})$ at $-20^{\circ} \mathrm{C}$.

\section{(3aR,4S,7aS)-9b}

$R_{f}=0.43$ (hexanes/EtOAc 5:1); $[\alpha]_{\mathrm{D}}{ }^{20}-29.2\left(c=0.62, \mathrm{CHCl}_{3}\right)$.

FT-IR: $3025(w), 2961(w), 2873(w), 1736(s), 1673(s), 1603(w)$, 1455 (w), 1385 (w), 1321 (w), 1257 (w), 1178 (w), $1136($ s), 1079 (w), $1051(w), 1024(w), 929(w), 909(w), 792(w), 710(w), 533(w)$, $487 \mathrm{~cm}^{-1}(\mathrm{w})$.

${ }^{1} \mathrm{H}$ NMR $\left(700 \mathrm{MHz}, \mathrm{CDCl}_{3}\right): \delta=1.29\left(\mathrm{t}, J=7.1 \mathrm{~Hz}, 3 \mathrm{H}, \mathrm{OCH}_{2} \mathrm{CH}_{3}\right), 1.39$ (dddd, $J=11.8,11.8,9.1,9.1 \mathrm{~Hz}, 1 \mathrm{H}, 1 \times 9-\mathrm{H}$ ), 1.41 (dddd, $J=12.3$, $12.3,8.9,8.9 \mathrm{~Hz}, 1 \mathrm{H}, 1 \times 7-\mathrm{H}), 1.77-1.84(\mathrm{~m}, 2 \mathrm{H}, 8-\mathrm{H}), 1.89$ (dddd, $J=11.6,6.0,6.0,5.4 \mathrm{~Hz}, 1 \mathrm{H}, 1 \times 9-\mathrm{H}), 2.05$ (dddd, $J=11.7,7.0,7.0$, $4.7 \mathrm{~Hz}, 1 \mathrm{H}, 1 \times 7-\mathrm{H}), 2.20$ (dddd, $J=13.1,11.7,6.4,6.4 \mathrm{~Hz}, 1 \mathrm{H}, 2-\mathrm{H}$ ), 2.29 (ddddd, $J=11.7,7.0,7.0,2.8,1.8 \mathrm{~Hz}, 1 \mathrm{H}, 1-\mathrm{H}$ ), 3.18 (d, $J=13.1 \mathrm{~Hz}, 1 \mathrm{H}, 3-\mathrm{H}), 4.24\left(\mathrm{~m}, 2 \mathrm{H}, \mathrm{OCH}_{2} \mathrm{CH}_{3}\right), 6.02(\mathrm{dd}, J=9.9,2.8 \mathrm{~Hz}$, $1 \mathrm{H}, 6-\mathrm{H}), 7.13$ (dd, $J=9.9,1.8 \mathrm{~Hz}, 1 \mathrm{H}, 5-\mathrm{H}$ ).

${ }^{13} \mathrm{C} \mathrm{NMR}\left(176 \mathrm{MHz}, \mathrm{CDCl}_{3}\right): \delta=13.2$ (C-12), 20.8 (C-8), 27.3 (C-7), 27.6 (C-9), 43.0 (C-1), 45.8 (C-2), 60.0 (C-11), 60.2 (C-3), 128.5 (C-6), $151.5(\mathrm{C}-5), 168.7$ (C-10), $194.1(\mathrm{C}-4)$.

MS (ESI): $m / z=231\left[\mathrm{M}+\mathrm{Na}^{+}\right], 209\left[\mathrm{M}+\mathrm{H}^{+}\right], 181,163,135$.

HRMS (ESI): $m / z\left[M+\mathrm{H}^{+}\right]$calcd for $\mathrm{C}_{12} \mathrm{H}_{17} \mathrm{O}_{3}{ }^{+}$: 209.1172; found: 209.1170.

\section{(3aR,4R,7aS)-9b}

$R_{f}=0.44$ (hexanes/EtOAc 5:1).

FT-IR: $2958(w), 2873(w), 1727(s), 1672(s), 1605(w), 1454(w)$, $1378(w), 1317(w), 1263(w), 1220(w), 1177(s), 1153(s), 1082(w)$, $1050(w), 1020(w), 954(w), 902(w), 803(w), 716(w), 609(w)$, $567(w), 527(w), 489(w), 442 \mathrm{~cm}^{-1}(w)$.

${ }^{1} \mathrm{H} \mathrm{NMR}\left(700 \mathrm{MHz}, \mathrm{CDCl}_{3}\right): \delta=1.25\left(\mathrm{t}, J=7.2 \mathrm{~Hz}, 2 \mathrm{H}, \mathrm{OCH}_{2} \mathrm{CH}_{3}\right), 1.35$ (dddd, $J=21.8,12.3,9.5,9.5 \mathrm{~Hz}, 1 \mathrm{H}, 1 \times 7-\mathrm{H}), 1.50-1.59(\mathrm{~m}, 1 \mathrm{H}$, $1 \times 9-\mathrm{H}), 1.75-1.83(\mathrm{~m}, 2 \mathrm{H}, 8-\mathrm{H}), 1.85$ (ddd, $J=11.9,6.1,6.1 \mathrm{~Hz}, 1 \mathrm{H}$, $1 \times 9-\mathrm{H}), 2.00-2.10(\mathrm{~m}, 2 \mathrm{H}, 2-\mathrm{H}, 1 \times 7-\mathrm{H}), 2.61-2.68(\mathrm{~m}, 1 \mathrm{H}, 1-\mathrm{H})$, $3.59(\mathrm{~d}, J=5.2 \mathrm{~Hz}, 1 \mathrm{H}, 3-\mathrm{H}), 4.16\left(\mathrm{~m}, 2 \mathrm{H}, \mathrm{OCH}_{2} \mathrm{CH}_{3}\right), 6.04(\mathrm{dd}, J=9.9$, $2.8 \mathrm{~Hz}, 1 \mathrm{H}, 6-\mathrm{H}), 7.14$ (dd, $J=9.9,1.8 \mathrm{~Hz}, 1 \mathrm{H}, 5-\mathrm{H})$.

${ }^{13} \mathrm{C}$ NMR $\left(176 \mathrm{MHz}, \mathrm{CDCl}_{3}\right): \delta=14.3\left(\mathrm{OCH}_{2} \mathrm{CH}_{3}\right), 21.6(\mathrm{C}-8), 26.9(\mathrm{C}-9)$, 28.1 (C-7), 40.1 (C-1), 46.1 (C-2), 56.2 (C-3), $61.1\left(\mathrm{OCH}_{2} \mathrm{CH}_{3}\right), 129.1$ (C6), 153.3 (C-5), 168.4 (C-10), 195.2 (C-4).

MS (ESI): $m / z=231\left[\mathrm{M}+\mathrm{Na}^{+}\right], 209\left[\mathrm{M}+\mathrm{H}^{+}\right], 163,135$. 
HRMS (ESI): $m / z\left[M+\mathrm{H}^{+}\right]$calcd for $\mathrm{C}_{12} \mathrm{H}_{17} \mathrm{O}_{3}{ }^{+}:$209.1172; found: 209.1192 .

(3aR,4R,5aR,6S,9R,9aS,9bR)-4-Acetyl-1,2,3,3a,4,5a,6,9,9a,9b-decahydro-5H-6,9-methanocyclopenta[a]naphthalen-5-one (keto-18) and $1-[(3 \mathrm{a} R, 5 \mathrm{a} R, 6 S, 9 R, 9 \mathrm{a} R, 9 \mathrm{~b} S)-5-\mathrm{Hydroxy}-2,3,3 \mathrm{a}, 5 \mathrm{a}, 6,9,9 \mathrm{a}, 9 \mathrm{~b}-\mathrm{oc}-$ tahydro-1H-6,9-methanocyclopenta[ $a]$ naphthalen-4-yl]ethanone (enol-18)

Method B: To a solution of (3aR,4R,7aS)-9a (127 mg, $713 \mu \mathrm{mol}$, 1 equiv) in anhyd toluene $\left(3.6 \mathrm{~mL}\right.$ ) under $\mathrm{N}_{2}$ atmosphere at $-100{ }^{\circ} \mathrm{C}$ was added dropwise TfOH ( $21.4 \mathrm{mg}, 143 \mu \mathrm{mol}, 0.2$ equiv) and the mixture stirred for 10 min prior to the addition of freshly distilled $\mathbf{1 7}$ ( $120 \mu \mathrm{L}, 94.2 \mathrm{mg}, 1.43 \mathrm{mmol}, 2$ equiv). The reaction mixture was warmed to $-75^{\circ} \mathrm{C}$ and stirred for $12 \mathrm{~h}$. After the addition of $\mathrm{NEt}_{3}$ $(0.3 \mathrm{~mL})$, the mixture was warmed to r.t. and the solvent removed under reduced pressure. Then $\mathrm{H}_{2} \mathrm{O}(5 \mathrm{~mL})$ was added and the solution extracted with $\mathrm{CH}_{2} \mathrm{Cl}_{2}(3 \times 10 \mathrm{~mL})$. The combined organic layers were dried $\left(\mathrm{MgSO}_{4}\right)$ and the solvent was removed under reduced pressure. The residue was taken up in EtOAc $(20 \mathrm{~mL})$ and filtered over a silica pad. The filtrate was concentrated under reduced pressure and the residue purified by chromatography on $\mathrm{SiO}_{2}$ with hexanes/EtOAc (gradient 30:1 $\rightarrow$ 10:1) to give a mixture of keto-18/enol-18 $=43: 57$ as a yellow oil; yield: $61.0 \mathrm{mg}$ [ $250 \mu \mathrm{mol}, 35 \%$; $40 \%$ referred to reisolated 9a $(16.0 \mathrm{mg}, 89.7 \mu \mathrm{mol})] ; 53 \quad R_{f}=0.47$ (hexanes/EtOAc 10:1); $[\alpha]_{\mathrm{D}}{ }^{20}-231.3\left(c=0.48, \mathrm{CHCl}_{3}\right.$, keto-18 : enol-18 $\left.=44: 56\right)$.

Both derivatives were characterized as mixture. For clarity the signals are listed separately.

\section{Enol-18}

${ }^{1} \mathrm{H}$ NMR $\left(700 \mathrm{MHz}, \mathrm{CDCl}_{3}\right): \delta=1.13-1.20(\mathrm{~m}, 1 \mathrm{H}, 1 \times 9-\mathrm{H}), 1.40$ (ddd, $J=8.2,1.6,1.6 \mathrm{~Hz}, 1 \mathrm{H}, 1 \times 16-\mathrm{H}), 1.43(\mathrm{~m}, 1 \mathrm{H}, 1 \times 7-\mathrm{H}), 1.50$ (ddd, $J=8.2,1.9,1.9 \mathrm{~Hz}, 1 \mathrm{H}, 1 \times 16-\mathrm{H}), 1.63-1.72(\mathrm{~m}, 1 \mathrm{H}, 1-\mathrm{H}), 1.72-1.76$ (m, $2 \mathrm{H}, 8-\mathrm{H}), 1.89-1.94(\mathrm{~m}, 1 \mathrm{H}, 1 \times 7-\mathrm{H}), 2.04-2.10(\mathrm{~m}, 2 \mathrm{H}, 2-\mathrm{H}$, $1 \times 9-\mathrm{H}), 2.12(\mathrm{~s}, 3 \mathrm{H}, 11-\mathrm{H}), 2.64(\mathrm{ddd}, J=9.2,5.9,3.2 \mathrm{~Hz}, 1 \mathrm{H}, 6-\mathrm{H})$, 3.00 (dd, $J=9.2,4.4 \mathrm{~Hz}, 1 \mathrm{H}, 5-\mathrm{H}), 3.01(\mathrm{~m}, 1 \mathrm{H}, 15-\mathrm{H}), 3.17(\mathrm{~m}, 1 \mathrm{H}$, $12-\mathrm{H}), 5.94(\mathrm{dd}, J=5.7,3.0 \mathrm{~Hz}, 1 \mathrm{H}, 13-\mathrm{H}), 6.05(\mathrm{dd}, J=5.7,3.0 \mathrm{~Hz}, 1 \mathrm{H}$, $14-\mathrm{H}), 16.67$ (s, $1 \mathrm{H}, \mathrm{OH})$.

${ }^{13} \mathrm{C}$ NMR (176 MHz, $\left.\mathrm{CDCl}_{3}\right): \delta=22.5(\mathrm{C}-8), 27.2(\mathrm{C}-7), 27.9(\mathrm{C}-11)$, 32.0 (C-9), 38.7 (C-2), 40.3 (C-6), 45.4 (C-15), 46.5 (C-1), 46.7 (C-5), 47.0 (C-12), 51.4 (C-16), 112.3 (C-3), 134.3 (C-13), 136.3 (C-14), $189.9,196.0(\mathrm{C}-4, \mathrm{C}-10)$.

\section{Keto-18}

FT-IR: $3057(w), 2960(w), 2869(w), 1716(s), 1687(s), 1570(w)$, $1453(w), 1418(w), 1358(w), 1309(w), 1252(w), 1211(w)$, $1146(w), 1050(w), 978(w), 933(w), 912(w), 865(w), 834(w)$, $753(w), 741(w), 695(w), 674(w), 602(w), 563(w), 529(w)$, $462 \mathrm{~cm}^{-1}(\mathrm{w})$.

${ }^{1} \mathrm{H}$ NMR (700 MHz, $\left.\mathrm{CDCl}_{3}\right): \delta=0.92-0.99(\mathrm{~m}, 1 \mathrm{H}, 1 \times 9-\mathrm{H}), 1.33$ (ddd, $J=8.4,1.6,1.6 \mathrm{~Hz}, 1 \mathrm{H}, 1 \times 16-\mathrm{H}), 1.43(\mathrm{~m}, 2 \mathrm{H}, 1 \times 7-\mathrm{H}, 1 \times 16-\mathrm{H})$, 1.65-1.71 (m, $1 \mathrm{H}, 1 \times 9-\mathrm{H}), 1.72-1.77(\mathrm{~m}, 3 \mathrm{H}, 1 \times 7-\mathrm{H}, 8-\mathrm{H}), 1.86$ (dddd, $J=12.4,12.4,7.1,7.1 \mathrm{~Hz}, 1 \mathrm{H}, 1-\mathrm{H}$ ), 1.98 (dddd, $J=12.4,12.4$, 10.8, 6.2 Hz, $1 \mathrm{H}, 2-\mathrm{H}$ ), 2.11 (s, $3 \mathrm{H}, 11-\mathrm{H}$ ), 2.77 (ddd, $J=9.2,7.1$, $3.2 \mathrm{~Hz}, 1 \mathrm{H}, 6-\mathrm{H}), 2.86(\mathrm{~d}, J=12.4 \mathrm{~Hz}, 1 \mathrm{H}, 3-\mathrm{H}), 2.91(\mathrm{dd}, J=9.2$, $4.4 \mathrm{~Hz}, 1 \mathrm{H}, 5-\mathrm{H}$ ), 3.03-3.05 (m, $1 \mathrm{H}, 15-\mathrm{H}$ ), 3.39 (dddd, $J=4.4,2.9,1.6$, $1.6 \mathrm{~Hz}, 1 \mathrm{H}, 12-\mathrm{H}), 6.08$ (dd, $J=5.7,2.9 \mathrm{~Hz}, 1 \mathrm{H}, 13-\mathrm{H}), 6.18$ (dd, $J=5.7$, $2.9 \mathrm{~Hz}, 1 \mathrm{H}, 14-\mathrm{H})$.
${ }^{13} \mathrm{C}$ NMR (176 MHz, $\left.\mathrm{CDCl}_{3}\right): \delta=22.2(\mathrm{C}-8), 27.3(\mathrm{C}-7), 29.2(\mathrm{C}-9)$, 29.8 (C-11), 39.4 (C-2), 40.0 (C-6), 44.6 (C-1), 45.6 (C-15), 47.9 (C-12), 50.3 (C-16), 51.8 (C-5), 70.3 (C-3), 135.9 (C-13), 137.3 (C-14), 206.3 (C-10), $210.4(C-4)$.

MS (ESI): $m / z=267\left[\mathrm{M}+\mathrm{Na}^{+}\right], 245\left[\mathrm{M}+\mathrm{H}^{+}\right], 179,137$.

HRMS (ESI): $m / z\left[\mathrm{M}+\mathrm{H}^{+}\right]$calcd for $\mathrm{C}_{16} \mathrm{H}_{20} \mathrm{O}_{2}{ }^{+}:$245.1536; found: 245.1538 .

\section{DFT Calculations}

The calculations were performed at the B3LYP 54 level of theory using the AUG-cc-pVTZ ${ }^{55}$ basis set as implemented in the Gaussian 16 program package. ${ }^{56}$ The X-ray crystal structure of enone 9a (Figure 2) served as a starting point to calculate optimized minimum energy structures of neutral (4R)-keto-18 and (4S)-keto-18 in their singlet ground states. Structures were optimized in the gas phase and confirmed to be true minima by frequency calculations (no imaginary frequencies). The relative free Gibbs energies $\left(\Delta \mathrm{G}_{\mathrm{GS}}\right)$ were extracted at $300 \mathrm{~K}$.

\section{Funding Information}

Generous financial support by the Ministerium für Wissenschaft, Forschung und Kunst des Landes Baden-Württemberg, the Fonds der Chemischen Industrie, the Deutsche Forschungsgemeinschaft (shared instrumentation grant INST 41/897-1 FUGG for $700 \mathrm{MHz}$ NMR) and the DAAD (DAAD-RISE fellowship for Y.S.) is gratefully acknowledged. J. L. would like to thank support by the state of Baden-Württemberg through bwHPC and the Deutsche Forschungsgemeinschaft through grant no. INST 40/467-1 FUGG (JUSTUS cluster).

\section{Supporting Information}

Michael reaction, aldol condensation, and Diels-Alder reaction as well as characterization of the synthesized compounds $\left({ }^{1} \mathrm{H},{ }^{13} \mathrm{C}\right.$ and NOESY spectra). Supporting information for this article is available online at https://doi.org/10.1055/s-0037-1610409.

\section{References}

(1) Eder, U.; Sauer, G.; Wiechert, R. Angew. Chem., Int. Ed. Engl. 1971, 10, 496.

(2) Hajos, Z. G.; Parrish, D. R. J. Org. Chem. 1974, 39, 1615.

(3) For some earlier organocatalysis, see: (a) Knoevenagel, E. Ber. Dtsch. Chem. Ges. 1898, 31, 2596. (b) Westheimer, F. H.; Cohen, H. J. Am. Chem. Soc. 1938, 60, 90.

(4) Reviews: (a) Dalko, P. I. Comprehensive Enantioselective Organocatalysis; Wiley-VCH: Weinheim, 2013. (b) List, B. Asymmetric Organocatalysis; Springer: Berlin, 2009.

(5) Selected reviews: (a) Klier, L.; Tur, F.; Poulsen, P. H.; Jørgensen, K. A. Chem. Soc. Rev. 2017, 46, 1080. (b) Chauhan, P.; Mahajan, S.; Enders, D. Acc. Chem. Res. 2017, 50, 2809. (c) Donslund, B. S.; Johansen, T. K.; Poulsen, P. H.; Halskov, K. S.; Jørgensen, K. A. Angew. Chem. Int. Ed. 2015, 54, 13860. (d) Hayashi, Y. J. Synth. Org. Chem., Jpn. 2014, 72, 1228. (e) Jiang, H.; Albrecht, L.; Dickmeiss, G.; Jensen, K. L.; Jørgensen, K. A. TMS-Prolinol Catalyst in Organocatalysis, In Comprehensive Enantioselective Organocatalysis; Dalko, P. I., Ed.; Wiley-VCH: Weinheim, 2013, 33-50. (f) Gotoh, H.; Hayashi, Y. Diarylprolinol silyl ethers: development and application as organocatalysts, In Sustainable Catal- 
ysis; Dunn, P. J., Ed.; Wiley: Hoboken, 2013, 287-316. (g) Jensen, K. L.; Dickmeiss, G.; Jiang, H.; Albrecht, L.; Jørgensen, K. A. Acc. Chem. Res. 2012, 45, 248. (h) Marques-Lopez, E.; Herrera, R. P. Curr. Org. Chem. 2011, 15, 2311. (i) Lattanzi, A. Chem. Commun. 2009, 1452. (j) Mielgo, A.; Palomo, C. Chem. Asian J. 2008, 3, 922. (k) Liu, J.; Wang, L. Synthesis 2017, 49, 960. (l) Marcos, V.; Alemán, J. Chem. Soc. Rev. 2016, 45, 6812.

(6) Reviews: (a) Renzi, P.; Hioe, J.; Gschwind, R. M. Acc. Chem. Res. 2017, 50, 2936. (b) Halskov, K. S.; Donslund, B. S.; Paz, B. M.; Jørgensen, K. A. Acc. Chem. Res. 2016, 49, 974. (c) Burés, J.; Armstrong, A.; Blackmond, D. G. Acc. Chem. Res. 2016, 49, 214. (d) Moberg, C. Angew. Chem. Int. Ed. 2013, 52, 2160.

(7) Selected examples: (a) Erdmann, H.; An, F.; Mayer, P.; Ofial, A. R.; Lakhdar, S.; Mayr, H. J. Am. Chem. Soc. 2014, 136, 14263. (b) Schmid, M. B.; Zeitler, K.; Gschwind, R. M. Chem. Sci. 2011, 2, 1793. (c) Schmid, M. B.; Zeitler, K.; Gschwind, R. M. J. Am. Chem. Soc. 2011, 133, 7065. (d) Dinér, P.; Kjærsgaard, A.; Lie, M. A.; Jørgensen, K. A. Chem. Eur. J. 2008, 14, 122. (e) Lakhdar, S.; Maji, B.; Mayr, H. Angew. Chem. Int. Ed. 2012, 51, 5739. (f) Burés, J.; Armstrong, A.; Blackmond, D. G. J. Am. Chem. Soc. 2011, 133, 8822. (g) Burés, J.; Armstrong, A.; Blackmond, D. G. J. Am. Chem. Soc. 2012, 134, 6741. (h) Patora-Komisarska, K.; Benohoud, M.; Ishikawa, H.; Seebach, D.; Hayashi, Y. Helv. Chim. Acta 2011, 94, 719. (i) Seebach, D.; Sun, X.; Sparr, C.; Ebert, M.-O.; Schweizer, W. B.; Beck, A. K. Helv. Chim. Acta 2012, 95, 1064. (j) Sahoo, G.; Rahaman, H.; Madarász, A.; Pápai, I.; Melarto, M.; Valkonen, A.; Pihko, P. M. Angew. Chem. Int. Ed. 2012, 51, 13144. (k) Seebach, D.; Sun, X.; Ebert, M.-O.; Schweizer, W. B.; Purkayastha, N.; Beck, A. K.; Duschmalé, J.; Wennemers, H.; Mukaiyama, T.; Benohoud, M.; Hayashi, Y.; Reiher, M. Helv. Chim. Acta 2013, 96, 799.

(8) (a) Lai, J.; Sayalero, S.; Ferrali, A.; Osorio-Planes, L.; Bravo, F.; Rodríguez-Escrich, C.; Pericàs, M. A. Adv. Synth. Catal. 2018, 360, 2914. (b) Szcześniak, P.; Staszewska-Krajewska, O.; Furman, B.; Mlynarski, J. Tetrahedron: Asymmetry 2017, 28, 1765. (c) Guryev, A. A.; Anokhin, M. V.; Averin, A. D.; Beletskaya, I. P. Mendeleev Commun. 2016, 26, 469. (d) Xia, A.-B.; Zhang, C.; Zhang, Y.-P.; Guo, Y.-J.; Zhang, X.-L.; Li, Z.-B.; Xu, D.-Q. Org. Biomol. Chem. 2015, 13, 9593. (e) Zheng, W.; Lu, C.; Yang, G.; Chen, Z.; Nie, J. Catal. Commun. 2015, 62, 34. (f) Keller, M.; Perrier, A.; Linhardt, R.; Travers, L.; Wittmann, S.; Caminade, A.M.; Majoral, J.-P.; Reiser, O.; Ouali, A. Adv. Synth. Catal. 2013, 355, 1748. (g) Wang, C. A.; Zhang, Z. K.; Yue, T.; Sun, Y. L.; Wang, L.; Wang, W. D.; Zhang, Y.; Liu, C.; Wang, W. Chem. Eur. J. 2012, 18, 6718. (h) Mager, I.; Zeitler, K. Org. Lett. 2010, 12, 1480.

(9) Sata, N. U.; Fusetani, N. Tetrahedron Lett. 2000, 41, 489.

(10) Jomon, K.; Kuroda, Y.; Ajisaka, M.; Sakai, H. J. Antibiot. 1972, 25 , 271.

(11) Kim, W. S.; Du, K.; Eastman, A.; Hughes, R. P.; Micalizio, G. C. Nat. Chem. 2018, 10, 70.

(12) Recent review: Eddy, N. A.; Ichalkaranje, P. Molecules 2016, 21, 1358.

(13) Evans, D. A.; Miller, S. J.; Lectka, T. J. Am. Chem. Soc. 1993, 115, 6460.

(14) Uenishi, J.; Kawahama, R.; Yonemitsu, O. J. Org. Chem. 1997, 62, 1691.

(15) (a) Krebs, M.; Kalinowski, M.; Frey, W.; Claasen, B.; Baro, A.; Schobert, R.; Laschat, S. Tetrahedron 2013, 69, 7373. (b) Evans, D. A.; Johnson, J. S. J. Org. Chem. 1997, 62, 786.

(16) Vosburg, D. A.; Vanderwal, C. D.; Sorenson, E. J. J. Am. Chem. Soc. 2002, 124, 4552.

(17) Shiina, J.; Nishiyama, S. Tetrahedron Lett. 2004, 45, 9033.
(18) Abd El-Gaber, M. K.; Yasuda, S.; Iida, E.; Mukai, C. Org. Lett. 2017, 19, 320.

(19) Clive, D. L. J.; Sunasee, R. Org. Lett. 2007, 9, 2677.

(20) (a) Wai, H. T.; Du, K.; Anesini, J.; Kim, W. S.; Eastman, A.; Micalizio, G. C. Org. Lett. 2018, 20, 6220. (b) Krebs, M.; Laschat, S. ARKIVOC 2012, (iii), 5.

(21) (a) Taber, D. F.; Malcolm, S. C. J. Org. Chem. 2001, 66, 944. (b) Pietrusiewicz, K. M.; Monkiewicz, J.; Bodalski, R. J. Org. Chem. 1983, 48, 788.

(22) Wilson, J. E.; Sun, J.; Fu, G. C. Angew. Chem. Int. Ed. 2010, 49, 161.

(23) Wang, Y.; Jaunet, A.; Geoffroy, P.; Miesch, M. Org. Lett. 2013, 15, 6198.

(24) Ressault, B.; Jaunet, A.; Geoffroy, P.; Goudedranche, S.; Miesch, M. Org. Lett. 2012, 14, 366.

(25) Minger, T. L.; Phillips, A. J. Tetrahedron Lett. 2002, 43, 5357.

(26) Holtsclaw, J.; Koreeda, M. Org. Lett. 2004, 6. 3719.

(27) Pfeiffer, M. W. B.; Phillips, A. J. J. Am. Chem. Soc. 2005, 127, 5334.

(28) (a) Schramm, M. P.; Reddy, D. S.; Kozmin, S. A. Angew. Chem. Int. Ed. 2001, 40, 4274. (b) Mézailles, N.; Ricard, L.; Gagosz, F. Org. Lett. 2005, 7, 4133.

(29) Mostafa, M. A. B.; Grafton, M. W.; Wilson, C.; Sutherland, A. Org. Biomol. Chem. 2016, 14, 3284.

(30) List, B.; Hoang, L.; Martin, H. J. Proc. Natl. Acad. Sci. U S A 2004, $101,5839$.

(31) Fonseca, M. T. H.; List, B. Angew. Chem. Int. Ed. 2004, 43, 3958.

(32) Yang, J.-D.; Kim, M.-S.; Lee, M.; Baik, W.; Koo, S. Synthesis 2000 , 801.

(33) Yamaguchi, M.; Yokota, N.; Minami, T. J. Chem. Soc., Chem. Commun. 1991, 1088.

(34) (a) Bernardi, L.; Fochi, M.; Carbone, R.; Martinelli, A.; Fox, M. E.; Cobley, C. J.; Kandagatla, B.; Oruganti, S.; Dahanukar, V. H.; Carlone, A. Chem. Eur. J. 2015, 21, 19208. For related work, see: (b) Ref. 32. (c) Ref. 33. (d) Ref. 35. (e) Ref. 51.

(35) Breistein, P.; Karlsson, S.; Hedenström, E. Tetrahedron: Asymmetry 2006, 17, 107.

(36) Pou, A.; Moyano, A. Eur. J. Org. Chem. 2013, 3103.

(37) Du, H.; Dudognon, Y.; Sanchez Duque, M.del Mar.; Goudedranche, S.; Bonne, D.; Rodriguez, J.; Bugaut, X.; Constantieux, T. Synthesis 2016, 48, 3479.

(38) Guevara-Pulido, J. O.; Andrés, J. M.; Ávila, D. P.; Pedrosa, R. RSC Adv. 2016, 6, 30166.

(39) Meyer, D.; Renaud, P. Angew. Chem. Int. Ed. 2017, 56, 10858.

(40) Beck, T. M.; Breit, B. Org. Lett. 2016, 18, 124.

(41) Singh, V.; Madapa, S.; Batra, S. Synth. Commun. 2008, 38, 2113.

(42) Fesenko, A. A.; Shutalev, A. D. Tetrahedron 2015, 71, 9528.

(43) Singh, V.; Batra, S. Synthesis 2006, 63.

(44) Peerzada, M. N.; Khan, P.; Ahmad, K.; Hassan, M. I.; Azam, A. Eur. J. Med. Chem. 2018, 155, 13.

(45) Waidmann, C. R.; Pierpont, A. W.; Batista, E. R.; Gordon, J. C.; Martin, R. L.; Pete Silks, L. A.; West, R. M.; Wu, R. Catal. Sci. Technol. 2013, 3, 106.

(46) Wang, Z. S.; Chen, L. Z.; Zhou, H. P.; Liu, X. H.; Chen, F. H. Bioorg. Med. Chem. Lett. 2017, 27, 1803.

(47) (a) CCDC 1878438 contains supplementary crystallographic data for the structure $(3 \mathrm{a} R, 4 R, 7 \mathrm{a} S)-9 \mathrm{a}$. The data can be obtained free of charge from The Cambridge Crystallographic Data Centre via www.ccdc.cam.ac.uk/getstructures. (b) Formula $\mathrm{C}_{11} \mathrm{H}_{14} \mathrm{O}_{2}$; size $0.570 \times 0.104 \times 0.096 \mathrm{~mm}$; crystal system: orthorhombic; space group: P2(1)2(1)2(1); unit cell dimensions: $a$ 5.3640(4) ,

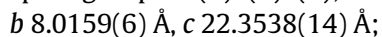
$\alpha=\beta=\gamma=90^{\circ}$.

(48) Ordóñez, M.; Guerrero de la Rosa, V.; Alcudia, F.; Llera, J. M. Tetrahedron 2004, 60, 871. 
(49) Kobayashi, Y.; Kiyotsuka, Y. Tetrahedron Lett. 2001, 42, 9229.

(50) (a) Smithen, D. A.; Forrester, A. M.; Corkery, D. P.; Dellaire, G.; Colpitts, J.; McFarland, S. A.; Berman, J. N.; Thompson, A. Org. Biomol. Chem. 2012, 11, 62. (b) Yuasa, Y.; Kato, Y. Org. Process Res. Dev. 2002, 6, 628. (c) Kenny, M.; Christensen, J.; Coles, S. J.; Franckevičius, V. Org. Lett. 2015, 17, 3926.

(51) Riaño, I.; Uria, U.; Carrillo, L.; Reyes, E.; Vicario, J. L. Org. Chem. Front. 2015, 2, 206.

(52) (a) Skrzyńska, A.; Romaniszyn, M.; Pomikło, D.; Albrecht, Ł. J. Org. Chem. 2018, 83, 5019. (b) Karageorgis, G.; Waldmann, H. Synthesis 2018, 50, in pressdoi: 10.1055/s-0037-1610368.

(53) (a) Bañuelos, P.; García, J. M.; Gómez-Bengoa, E.; Herrero, A.; Odriozola, J. M.; Oiarbide, M.; Palomo, C.; Razkin, J.J. Org. Chem. 2010, 75, 1458. (b) Palomo, C.; Oiarbide, M.; García, J. M.; González, A.; Lecumberri, A.; Linden, A. J. Am. Chem. Soc. 2002, $124,10288$.

(54) (a) Miehlich, B.; Savin, A.; Stoll, H.; Preuss, H. Chem. Phys. Lett. 1989, 157, 200. (b) Becke, A. D. J. Chem. Phys. 1993, 98, 5648.
(55) Dunning, T. H. J. Chem. Phys. 1989, 90, 1007.

(56) Frisch, M. J.; Trucks, G. W.; Schlegel, H. B.; Scuseria, G. E.; Robb, M. A.; Cheeseman, J. R.; Scalmani, G.; Barone, V.; Petersson, G. A.; Nakatsuji, H.; Li, X.; Caricato, M.; Marenich, A. V.; Bloino, J.; Janesko, B. G.; Gomperts, R.; Mennucci, B.; Hratchian, H. P.; Ortiz, J. V.; Izmaylov, A. F.; Sonnenberg, J. L.; Williams-Young, D.; Ding, F.; Lipparini, F.; Egidi, F.; Goings, J.; Peng, B.; Petrone, A.; Henderson, T.; Ranasinghe, D.; Zakrzewski, V. G.; Gao, J.; Rega, N.; Zheng, G.; Liang, W.; Hada, M.; Ehara, M.; Toyota, K.; Fukuda, R.; Hasegawa, J.; Ishida, M.; Nakajima, T.; Honda, Y.; Kitao, O.; Nakai, H.; Vreven, T.; Throssell, K.; Montgomery, J. A. Jr.; Peralta, J. E.; Ogliaro, F.; Bearpark, M. J.; Heyd, J. J.; Brothers, E. N.; Kudin, K. N.; Staroverov, V. N.; Keith, T. A.; Kobayashi, R.; Normand, J.; Raghavachari, K.; Rendell, A. P.; Burant, J. C.; Iyengar, S. S.; Tomasi, J.; Cossi, M.; Millam, J. M.; Klene, M.; Adamo, C.; Cammi, R.; Ochterski, J. W.; Martin, R. L.; Morokuma, K.; Farkas, O.; Foresman, J. B.; Fox, D. J. Gaussian 16, Revision B.01; Gaussian, Inc: Wallingford CT, 2016. 